\title{
The Molecular Characteristics of Non-Clear Cell Renal Cell Carcinoma: What's the Story Morning Glory?
}

\author{
Andrea Marchetti ${ }^{1,+}+\mathbb{D}$, Matteo Rosellini ${ }^{1,+}+\mathbb{D}$, Veronica Mollica ${ }^{1}$, Alessandro Rizzo $\left.{ }^{1} \mathbb{(}\right)$, Elisa Tassinari ${ }^{1}$, \\ Giacomo Nuvola ${ }^{1}\left(\mathbb{D}\right.$, Alessia Cimadamore ${ }^{2}$, Matteo Santoni ${ }^{3}$, Michelangelo Fiorentino ${ }^{4}{ }^{(}$, \\ Rodolfo Montironi ${ }^{2, \ddagger(1)}$ and Francesco Massari ${ }^{1, *, \neq(\mathbb{D}}$
}

check for updates

Citation: Marchetti, A.; Rosellini, M. Mollica, V.; Rizzo, A.; Tassinari, E.; Nuvola, G.; Cimadamore, A.; Santoni, M.; Fiorentino, M.; Montironi, R.; et al. The Molecular Characteristics of Non-Clear Cell Renal Cell Carcinoma: What's the Story Morning Glory? Int. J. Mol. Sci. 2021, 22, 6237. https:// doi.org/10.3390/ijms22126237

Academic Editor: David Meierhofer

Received: 23 May 2021

Accepted: 8 June 2021

Published: 9 June 2021

Publisher's Note: MDPI stays neutral with regard to jurisdictional claims in published maps and institutional affiliations.

Copyright: (c) 2021 by the authors. Licensee MDPI, Basel, Switzerland. This article is an open access article distributed under the terms and conditions of the Creative Commons Attribution (CC BY) license (https:/ / creativecommons.org/licenses/by/ $4.0 /)$.
1 Medical Oncology, IRCCS Azienda Ospedaliero-Universitaria di Bologna, Via Albertoni-15, 40138 Bologna, Italy; andrea.marchetti12@studio.unibo.it (A.M.); matteorosellini92@gmail.com (M.R.); veronica.mollica7@gmail.com (V.M.); rizzo.alessandro179@gmail.com (A.R.); elisa.tassinari95@gmail.com (E.T.); giacomo.nuvola87@gmail.com (G.N.)

2 Section of Pathological Anatomy, School of Medicine, Polytechnic University of the Marche Region, United Hospitals, 60126 Ancona, Italy; a.cimadamore@staff.univpm.it (A.C.); r.montironi@staff.univpm.it (R.M.)

3 Oncology Unit, Macerata Hospital, 62100 Macerata, Italy; mattymo@alice.it

4 Department of Specialistic Diagnostic and Experimental Medicine, University of Bologna, Via Massarenti 9, 40138 Bologna, Italy; michelangelo.fiorentino@unibo.it

* Correspondence: fmassari79@gmail.com; Tel.: +39-0512142575

+ Equally Contributing First Authors.

$\ddagger$ Equally Contributing Last Authors.

Abstract: Non-clear cell renal cell carcinomas are a miscellaneous group of tumors that include different histological subtypes, each one characterized by peculiarity in terms of genetic alteration, clinical behavior, prognosis, and treatment response. Because of their low incidence and poor enrollment in clinical trials, alongside their heterogeneity, additional efforts are required to better unveil the pathogenetic mechanisms and, consequently, to improve the treatment algorithm. Nowadays, tyrosine kinase inhibitors, mTOR and MET inhibitors, and even cisplatin-based chemotherapy and immunotherapy are potential weapons that are still under evaluation in this setting. Various biomarkers have been evaluated for detecting progression and monitoring renal cell carcinoma, but more studies are necessary to improve this field. In this review, we provide an overview on the molecular characteristics of this group of tumors and the recently published trials, giving an insight into what might become the future therapeutic standard in this complex world of non-clear cell kidney cancers.

Keywords: non-clear cell renal cell carcinoma; papillary RCC; chromophobe RCC; TKI; immunotherapy; molecular targets; pathways; VEGFR; mTOR; MET

\section{Introduction}

Renal cell carcinoma (RCC) is the 7th and the 10th most common cancer in male and female population respectively, with a worldwide estimate for 2020 of more than 431,000 new cases and more than 179,000 deaths [1]. The incidence of this cancer is greater from the sixth to eighth decades and usually they are diagnosticated during exams performed for other reasons [2]. More than 65\% of all RCC are localized at the diagnosis and in this setting $90 \%$ of patients survive at least 5 years [3]. On the other hand, the prognosis is poorer in metastatic patients and the mortality rate per year is about $4 / 100,000$ people in the Western world. [4].

Generally, kidney cancer can be divided in two main histological groups: clear cell renal cell carcinoma (ccRCC), representing about 75-80\% of all cases of RCC, and non-clear cell renal cell carcinoma (nccRCC), that includes several histologic subtypes differing in terms of cellular morphology, molecular alterations and gene expression, prognosis, and response to therapy. Among nccRCC, the most frequent histologic entities are chromophobe (chRCC) and papillary renal cell carcinoma (pRCC). The latter can be distinguished into 
type $1 \mathrm{pRCC}$ (basophilic) and type $2 \mathrm{pRCC}$ (eosinophilic). Nonetheless, there are many less common subtypes considered part of the nccRCC group: medullary RCC, collecting duct RCC, oncocytoma, translocation RCC, tubulocystic RCC, and hereditary leiomyomatosis and RCC (HLRCC)-associated RCC [5,6]. About 5\% of RCC remain unclassified due to their histological features that do not fit into any of the well-recognized subtypes [6]. Even though most nccRCCs tumors are sporadic, approximately $5 \%$ may present a genetic predisposition [7]. Hereditary renal cancers are more often multiple and bilateral and, usually, occur at an earlier age than the non-familial renal tumors [8].

Nowadays, our knowledge about the sarcomatoid and/or rhabdoid dedifferentiation of RCC (S/R RCC) patients is typically associated with poor prognosis. Even though the treatment scenario for metastatic ccRCC has significantly evolved over the past decade, with multiple targeted therapies and immune checkpoint inhibitors (ICI)-based regimens approved, very little progress has been made in the therapeutic management of advanced nccRCC $[9,10]$. As a matter of fact, patients with metastatic nccRCC have usually not been included in phase III trials, due to the low incidence of these tumors along with their clinical and molecular heterogeneity. This lack of available data has led physicians to treat nccRCC patients with a limited number of therapies, even adopting the same algorithm used in cCRCC.

In the last few years, an extensive molecular description of the key pathogenetic alterations in the major forms of tumors, among which RCC is noteworthy, has been performed by the Cancer Genome Atlas (TCGA), a collaboration between the National Cancer Institute and the National Human Genome Research Institute [11]. Nowadays the increased knowledge of these molecular findings grants a novel integration of histopathological and genomic aspects, which progressively paves the way for a personalization of RCC clinical management. Focusing on nccRCC, the recent genome sequencing studies have highlighted how important it is to consider the many subtypes included in this group as standalone entities, since each of these is characterized by a specific spectrum of molecular altered pathways differing from the tumor's morphology, immune-histochemical features, but also response to systemic treatments, clinical behavior, and prognosis (Figure 1) [12]. These pivotal differences could be exploited to improve the therapeutic management of nccRCC.

The aim of this paper is to describe the most important signaling pathways involved in the nccRCC oncogenesis, highlighting the newly described molecular characteristics of each histotype, and mostly paying attention to potential targets for current and future therapeutic strategies (Figure 2). We also discuss the molecular characterization of RCC with sarcomatoid dedifferentiation and their management in the light of recent published trials. In addition, we provide an overview of the most significant ongoing and recently published trials (testing immunotherapies or targeted therapies) that involved patients with nccRCC. We performed a research on PubMed/Medline, Cochrane Library, and Scopus using the keywords "non-clear cell renal cell carcinom", "advanced nccRCC", "metastatic nccRCC", and "molecular characterization" or "genomic profiling" or "molecular targets". We consulted case reports, reviews, and original articles, from 1996 to the current year. 


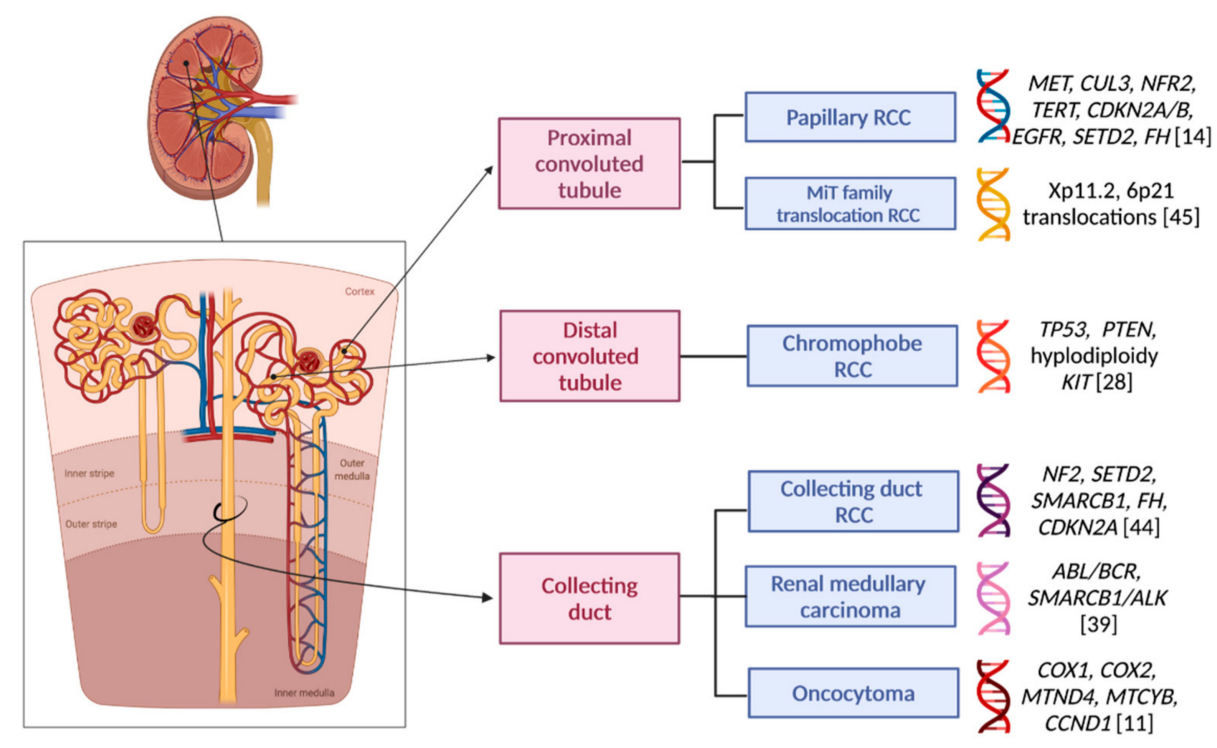

Figure 1. The papillary renal cell carcinoma ( $\mathrm{pRCC}$ ) has been shown to originate from the proximal convoluted tubule's epithelium, along with the MiT family translocation RCCs. Chromophobe RCC originates from intercalated cells in the distal convoluted tubule, while collecting duct RCC, oncocytoma, and renal medullary carcinoma (RMC) appear to originate from distal collecting duct principal or calyceal cells [6]. In this figure the most common genetic abnormalities are suggested for each of these non-clear cell histotypes [11]. Created by BioRender.com (accessed on 8 May 2012).

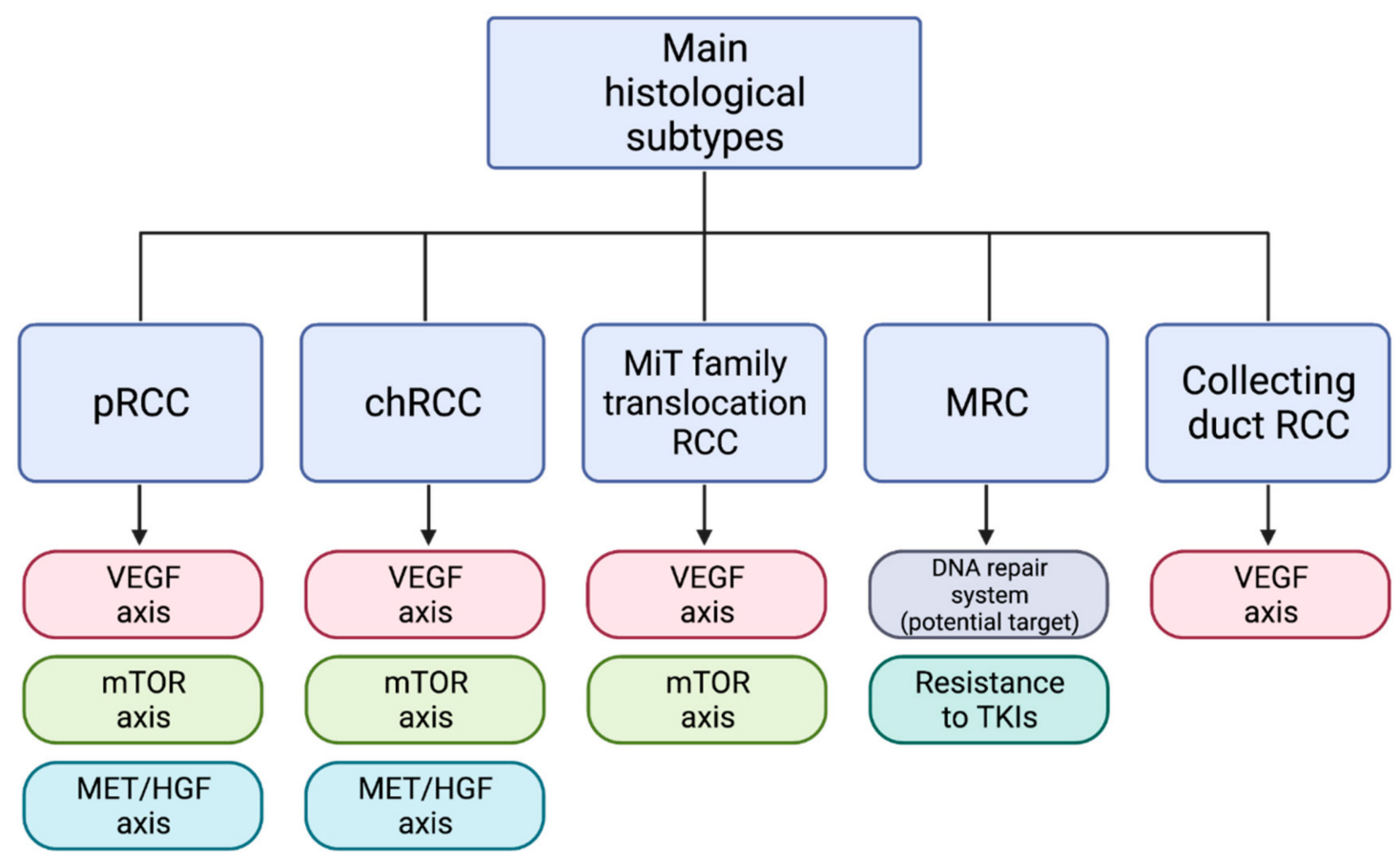

Figure 2. Workflow diagram of the molecular targets of the main histological subtypes of nccRCC. Abbreviations: pRCC = papillary renal cell carcinoma; chRCC $=$ chromophobe RCC; $\mathrm{MRC}=$ medullary renal cell carcinoma; VEGF = vascular endothelial growth factor; $\mathrm{mTOR}=$ mammalian target of rapamycin; MET = mesenchymal epithelial transition or hepatocyte growth factor receptor; HGF = hepatocyte growth factor; TKIs = tyrosine kinase inhibitors. Created by BioRender.com (accessed on 8 June 2021). 


\section{Main Histological Subtypes}

\subsection{Papillary RCC}

The most frequent subtype of nccRCC is papillary RCC (pRCC), which is also the second most common carcinoma of the renal tubules after ccRCC, accounting for $10-15 \%$ of all kidney cancers. In more detail, pRCC is a heterogeneous disease that involves indolent malignancies with a multifocal presentation as well as solitary tumors with an aggressive phenotype. As for the histological aspect, pRCC is constituted by malignant cells histologically arranged in a papillary pattern, that are derived from proximal tubule epithelium. The papillae are supported by a fibrous-vascular axis, infiltrated by foamy macrophages, and characterized by cholesterinic necrosis and psammoma bodies. Frequent hemorrhagic or necrotic foci and cystic degeneration are described. Of note, a poor prognosis may be correlated with the sarcomatoid dedifferentiation of the tumor along with the coexistence of clear cells [13]. The entity of pRCC is classically subdivided in two main subtypes, type 1 and type 2 pRCC, based on their histopathological appearance. Furthermore, type 1 and type 2 pRCC are shown to differ from each other due to their clinical and also biological features $[5,14]$. Type $1 \mathrm{pRCC}$ is typically associated with better prognosis and a more indolent behavior: it has a slow growth rate along with a low tendency to metastasize. From a microscopic point of view, it is characterized by regular layers of basophilic cells with large round nuclei and poor cytoplasm, as well as a poor vascular bed. On the other side, aggregates of eosinophilic cells organized to form papillae are found in type $2 \mathrm{pRCC}$, highlighting more aggressive features, such as polymorphic irregular nuclei with nucleoli, infiltrating foamy macrophages and psammoma bodies [15]. Moreover, type 2 pRCC is characterized by a higher pathological grade and worse tumor stage at the moment of the diagnosis than type 1 pRCC, confirming the worst course of this disease. As a matter of fact, type 2 pRCC is associated with poorer survival outcomes [16,17]. According to the 2016 WHO classification, mixed histologies have been recently accepted as part of the pRCC group, including the so-called oncocytic-papillary RCC or the clear cell papillary RCC (ccpRCC) $[5,18]$. The first studies on the pRCC genomic profile were conducted in the late 1990s, focusing on patients affected by hereditary pRCC (HPRCC). Researchers identified activating mutations of $M E T$ proto-oncogene as the main pathogenetic mechanism in the development of this hereditary cancer syndrome [19]. Further genomic profiling studies on somatic pRCC patients showed how commonly MET mutations may be discovered in type 1 pRCC cases [14]. Notably, sporadic type 1 pRCC is associated with genetic abnormalities, such as gains or trisomy of chromosomes 7 (whose long arm contains MET proto-oncogene), 17 and less frequently 2, 3, 12, 16, and 20. On the other hand, type 2 pRCC has been recently shown to be a heterogeneous group, which may be divided into three separate subtypes, according to their molecular differences along with patients' survival outcomes. Mutations of SETD2, NF2, CUL3, TERT promoter, as well as CDKN2A silencing, increased expression of the NRF2-antioxidant pathway and gains of chromosomes 7, 12, 16, and 17 are described in sporadic type 2 pRCC patients [20,21]. Negative prognostic factors observed in type $2 \mathrm{pRCC}$ are represented by CpG island methylator phenotype and $9 p$ loss [14]. Genetic alterations of the fumarate hydratase gene (HF) have been frequently displayed in a rare hereditary form of type 2 pRCC, described among patients affected by hereditary leiomyomatosis RCC (HLRCC) [12,22]. The above-mentioned molecular differences between type 1 and type 2 pRCC have been reported in the Cancer Genome Atlas (TCGA) profiling, which largely reflects localized disease. As for advanced disease, other molecular differences have been described between type 1 pRCC (MET 33\%, TERT $30 \%, C D K N 2 A / B 13 \%$, and EGFR $8 \%$ ) and type 2 pRCC (CDKN2A/B 18\%, TERT $18 \%$, NF2 $13 \%$, $F H 13 \%$, and MET $7 \%$ ) in further studies. These differences are extremely noteworthy due to their future use as targets for specific therapies for the metastatic setting management [23]. 


\subsection{Chromophobe RCC}

Chromophobe renal cell carcinoma (chRCC) is the third most common subtype of RCC, representing about $5 \%$ of all the cases and originates from the intercalated cells of the collecting duct [24].

This neoplasia is characterized by two main varieties of cells: pale and eosinophilic cells. Pale cells are large with rich cytoplasm and plant-like membrana. The eosinophilic ones are smaller and present granular eosinophilic cytoplasm. The eosinophilic variant is predominantly composed of these latter types of cells [25]. A Furham or WHO/ISUP nuclear grade cannot be assigned due to the abundant nuclear atypia [26]. Usually, this tumor affects young patients, mostly female, and it is mainly diagnosed at an early stage [27]. A peculiar aspect of chRCC is its aneuploidy, given by substantial chromosomal loss, while somatic mutations are less frequent than in ccRCC. Among these, TP53 and PTEN are the most common alterations (PTEN is associated with poor prognosis), even if it is possible to detect mutations also in mTOR, NRAS, and TSC1 and $2[28,29]$. Several rare genetic syndromes are associated with chRCC: Birt-Hogg-Dubé syndrome, BAP1 tumor predisposition syndrome, tuberous sclerosis, Cowden syndrome, and hereditary paraganglioma/pheochromocytoma syndrome (all autosomal dominant diseases) [30]. Generally, chromophobe RCC has a better prognosis if compared to ccRCC (with greater than $90 \%$ 10-year survival) but the presence of sarcomatoid differentiation provides a more aggressive behavior and a worse outcome [31].

\subsection{RCC with Sarcomatoid/Rhabdoid Features}

Sarcomatoid and rhabdoid renal cell carcinoma (S/R RCC) represents an aggressive form of dedifferentiation of RCC, coexisting with other variants in approximately $10-15 \%$ of patients, whichever is the predominant subtype of kidney cancer. Sarcomatoid and rhabdoid features may occur in the same neoplasia or independently from each other, and it represents the progressive evolution from a differentiated to an undifferentiated RCC. As a consequence, S/R RCC carries a poor prognosis, being characterized by an aggressive behavior; as a matter of fact, most patients with S/R RCC are metastatic at the diagnosis and witness a rapid clinical progression [32,33]. Both the sarcomatoid and epithelial components of the neoplasia share a common progenitor cell, but the clonal evolution during the oncogenesis leads to several genetic abnormalities in cells that are going to take part of the sarcomatoid component, triggering the so-called epithelial-to-mesenchymal transition (EMT) and hesitating in intratumoral genetic heterogeneity [34]. An expanded clinical and molecular integrated characterization of S/R RCC, built on data from clinical trials and real-world cohorts, has been recently carried out by Bakouny and colleagues, shedding light on the molecular drivers of aggressivity and responsiveness to therapies of these so far little known histotypes [35]. First of all, S/R RCCs are characterized by the enrichment of $M Y C$-regulated genes, along with multiple molecular pathways involved in cell cycle regulation and tumor's invasiveness. The upregulation of these MYC-related genes correlates with the poor quoad vitam prognosis of these histotypes, thus unveiling its pathogenetic key role as molecular driver of aggressivity of S/R RCCs [35]. According to prior studies, several mutations regarding the Hippo pathway (including NF2 gene's ones) have been marked in sarcomatoid RCC, while BAP1 abnormalities have been shown to relate to sarcomatoid as well as rhabdoid RCC tumors. $C D K N 2 A / B$ deletions have been reported more frequently in S RCC tumors, even though they are also present in R RCC and non-S/R RCC tumors. Moreover, we may keep in mind, the depletion of S/R RCC molecular markers in KDM5C mutations and the enrichment in EZH2 amplifications, too [36-38]. The overexpression of aurora kinase A with an increased mTOR activity has been described in sarcomatoid cells sampled from eight nephrectomized patients, with the help of RNA sequencing. Nonetheless, mTOR inhibitors seem not to be so effective in S/R RCC treatment [39]. Furthermore, the current characterization highlights the increased PD-L1 expression in S/R RCC malignant cells, along with an enriched CD8+ T cell intratumoral infiltration. Notably, S/R RCC tumors are shown to exhibit an immuno- 
inflamed phenotype, explaining consequently their noticeable responsiveness to ICIs. S/R RCC cells display an overexpression of all 8 "Hallmark" immune gene sets (including IL6-JAK-STAT3 signaling and IF gamma response). Moreover, an immune responsive microenvironment is significantly expressed in S/R RCC tumors, including elements such as M1 macrophages, Th1 T cell subsets, or activated NK cells [35]. Lastly, mutations in specific tumor suppressor genes (in particular TP53, but also ARID1A) are described as very common findings in sarcomatoid and rhabdoid components of S/R RCCs [40].

\subsection{Collecting Duct RCC}

Collecting duct RCC (cdRCC; also known as Bellini duct carcinoma) originates from the principal cells of distal collecting ducts, accounting for less than $1 \%$ of all RCC. It has a very poor prognosis and about 1 patient of 3 presents metastasis at the diagnosis. This rare subtype of RCC is composed of two main histological features, a desmoplastic stroma and a glandular part with an atypical epithelium [41]. It has been observed a morphologic and a cytogenetic similarity with urothelian cell carcinoma, also sharing a close clinical behavior [42]. For these reasons, chemotherapy regimens also used in urothelial carcinoma may be appropriate, although the prognosis still remains poor [43]. A NGS of prespecified genes panel performed on 17 patients with cdRCC highlighted genomic alterations in SETD2, CDKN2A, SMARCB1, and NF2 (the latter has been revealed in one third of the cohort) [44].

\subsection{MiT Family Translocation RCC}

MiT family translocation RCC is a rare and aggressive variety of RCC arising in the pediatric population and in young adults. This group of aggressive tumors are characterized by various translocations, most of them involve the transcription factor E3 (TFE3) that is located on chromosome X (Xp11.2) [45]. Tumors associated with Xp11 and $t(6 ; 11)$ translocations are the most frequent and morphologically described tumors of this family. Xp11 translocation and, in general, MiT family translocation RCC that develop in adult age could have an aggressive behavior and spread early in lymph nodes [46].

Translocation RCC presents a papillary and/or alveolar pattern, with large eosinophilic and/or clear cells and the pathological diagnosis is supported by the nuclear immunoreactivity of TFE3 [47]. Moreover, TFE3-positive tumors are more likely to be diagnosed at an advanced stage and a more aggressive behavior is noticed when it displays in adults $[48,49]$.

\subsection{Renal Medullary Carcinoma}

Renal medullary carcinoma (RMC) is a rare and extremely aggressive variant of renal cell carcinoma and mainly affects African young male with sickle cell trait. Less than $5 \%$ of patients survive more than 3 years [50]. RMC is treated with platinum-based chemotherapy due to its intrinsic resistance to all the targeted therapy used in the other RCCs. New data coming from recent work suggest the potential role of agents targeting replication stress pathways (for example PARP inhibitors) in the treatment of this rare subtype, but further investigations are required [51]. Transcriptomic analysis of RMC samples showed similar gene expression features between RMC and chRCC. One of the most frequent alterations evidenced in RMC is in SMARCB1 gene [39].

In Table 1 are reported the non-clear cell histological subtypes of RCC with their features. 
Table 1. Histotypes categorized as non-clear cell renal cell carcinoma (nccRCC) along with their epidemiological features and genetic abnormalities.

\begin{tabular}{|c|c|c|c|}
\hline Histotype & $\begin{array}{c}\text { Frequency } \\
\text { (\% of All RCCs) }\end{array}$ & Cytogenetic Mutations & Genes Altered \\
\hline Type 1 papillary RCC & $\begin{array}{c}10-15 \% \text { (considering all } \\
\text { pRCCs) }\end{array}$ & $\begin{array}{l}+3 q,+7,+8 q,+12 q,+16 p \\
+17,+20,-9 p,-Y\end{array}$ & $\begin{array}{l}\text { MET, CUL3, NFR2, TERT, } \\
\text { CDKN2A/B, EGFR }\end{array}$ \\
\hline Type 2 papillary RCC & $\begin{array}{c}10-15 \% \text { (considering all } \\
\text { pRCCs) }\end{array}$ & $\begin{array}{c}+7,+8 \mathrm{q},+12,+16,+17 \\
-1 \mathrm{p},-9 \mathrm{p}, \mathrm{CpG} \text { island } \\
\text { methylator }\end{array}$ & $\begin{array}{l}\text { CDKN2A silencing, SETD2, } \\
\text { NF2, CUL3, TERT promoter, } \\
\text { fumarate hydratase }(F H)\end{array}$ \\
\hline Chromophobe RCC & $5 \%$ & $\begin{array}{c}-1,-2,-6,-7,-10,-13,-17 \\
-21\end{array}$ & $\begin{array}{c}\text { TP53, PTEN, hypodiploidy } \\
\text { KIT }\end{array}$ \\
\hline Oncocytoma & $3-7 \%$ & $\begin{array}{l}\text { Diploid karyotype, } \\
\text { loss of chromosome } 1 \text { or } \mathrm{Y}, \\
\text { or rearrangement of } 11 \mathrm{q} 13 .\end{array}$ & $\begin{array}{c}\text { Mitochondrial genes } \\
\text { (COX1, COX2, MTND4, } \\
\text { MTCYB). } \\
\text { The 11q13 rearrangement may } \\
\text { affect the CCND1 gene. }\end{array}$ \\
\hline $\begin{array}{l}\text { Collecting duct carcinoma } \\
\text { (also known as Bellini's } \\
\text { carcinoma) }\end{array}$ & $1 \%$ & $-1 q,-8 p,-9 p,-16 p,+13 q$ & $\begin{array}{c}\text { NF2, SETD2, SMARCB1, } \\
F H, C D K N 2 A\end{array}$ \\
\hline Medullary RCC & $1 \%$ & $\begin{array}{c}A B L / B C R \text { (rare), } \\
S M A R C B 1 / A L K \text { (rare), } \\
\text { monosomy } 11\end{array}$ & Not defined \\
\hline MiT family translocation RCC & $1 \%$ & $\begin{array}{l}\text { Recurrent translocations } \\
\text { involving } \mathrm{Xp} 11.2 \text { (TFE3) } \\
\text { or } 6 \mathrm{p} 21 \text { (TFEB) }\end{array}$ & Not defined \\
\hline $\begin{array}{l}\text { Multilocular cystic renal } \\
\text { neoplasm of low malignant } \\
\text { potential }\end{array}$ & $<1 \%$ & Not defined & Not defined \\
\hline $\begin{array}{c}\text { Hereditary leiomyomatosis } \\
\text { with RCC }\end{array}$ & $<1 \%$ & Not defined & $F H$ \\
\hline $\begin{array}{c}\text { Succinate } \\
\text { dehydrogenase-deficient RCC }\end{array}$ & $<1 \%$ & Not defined & $S D H$ (double hit inactivation) \\
\hline $\begin{array}{c}\text { Acquired cystic } \\
\text { kidney disease-associated } \\
\text { RCC }\end{array}$ & $<1 \%$ & $+3,+7,+17,-Y$ & Not defined \\
\hline Unclassified RCC & about $5 \%$ & Not defined & Not defined \\
\hline
\end{tabular}

Abbreviations: $\mathrm{RCC}=$ renal cell carcinoma; $\mathrm{pRCC}=$ papillary renal cell carcinoma

\section{Molecular Targets}

\subsection{VEGF Axis Pathway}

The role of angiogenesis in the growth of organs and tumors is widely recognized. Angiogenesis is an intricate process strictly regulated via a complex balance between proangiogenic and antiangiogenic factors, whose synthesis and excretion may depend on the tumor itself as well as the neighboring extracellular matrix cells in the malignant microenvironment [52]. Chemokines, a superfamily of structurally homologous heparinbinding proteins, participate in this complex mechanism due to their power to induce and even inhibit angiogenesis [53]. 
With regards to malignant tumors, the above-described tight equilibrium is titled in favor of angiogenesis. In more detail, the abnormal cancer-related angiogenesis appears to be frequently related to tumor hypoxia, caused by an uncontrolled malignant proliferation contemporary to a poor expansion of the vascular bed [54]. Among the pro-angiogenic factors, the vascular endothelial growth factor (VEGF) is the pivotal heparin-binding polypeptide that modulates angiogenesis by interacting with tyrosine kinase VEGF receptors, VEGFR1 (also known as FLT1) and VEGFR2 (also indicated as KDR or FLK1) [55]. The synthesis of VEGF is induced by hypoxia, and the VEGF signaling pathway appears to be upregulated in several human cancers, with a remarkable and well-known implication in RCC tumorigenesis. Notably, the biallelic inactivation of the Von Hippel-Lindau (VHL) tumor suppressor gene occurs in the vast majority of RCC (particularly in the clear cell histotype), leading to the accumulation of hypoxia-inducible factors and overexpression of several genes, including those for VEGF [56]. By the way, different RCC histotypes appear to be related to different expressions of VEGF, VEGFR1, and VEGFR2 mRNA levels. The expression patterns of VEGF and its tyrosine kinase receptors were shown to be higher in cCRCC than in pRCC in a 2006 Swedish study, pointing out that different pathways are likely involved in regulating angiogenesis in the different RCC histotypes [57]. As proof of this, the initial oncogenic event for nccRCC seems not to be VHL-driven, explaining the poor rate of VHL mutations among non-clear cell histologies [58]. The importance of this finding is to be found in the resulting therapeutic management of nccRCC. Patients with metastatic nccRCC are characterized by a worse response to VEGF/VEGFR-targeted therapies, as well as a shorter OS, if compared to ccRCC patients [4]. Of interest, RCC patients with wild type VHL along with TP53 and FLT1 mutations were shown to be related with shorter progression-free survival (PFS) in response to VEGF-targeted treatments, compared to RCC patients with genetic abnormalities of the VHL gene. As described above, these genetic profiles distinguish non-clear cell histotypes, remarking the worse response to VEGF-targeted therapies of nccRCCs [59]. A still-today pivotal VEGFR-targeted agent in metastatic ccRCC treatment as sunitinib did not display the same expected efficacy when investigated in the non-clear cell setting. The prospective phase II trials ASPEN and ESPN compared the administration of sunitinib with mTOR inhibitor everolimus in metastatic nccRCC patients not previously treated with TKIs. Whereas the ASPEN trial reported a better PFS in the sunitinib group compared to patients treated with everolimus (hazard ratio (HR) 1.41, 80\% confidence interval $(\mathrm{CI}): 1.03-1.92, p=0.16$ ) along with a comparable mOS (HR 1.12, 95\% CI: 0.7-2.1) [60], no survival benefits were shown to be related to the administration of sunitinib if compared to everolimus, in the ESPN study (HR for PFS 1.16, 95\% CI: 0.67-2.01) [61].

Similar PFS rates for sunitinib and everolimus (HR 1.5, 95\% CI: 0.9-2.8) with regards to non-clear cell histotypes were shown in subgroup analysis of the 2014 phase II RECORD3 trial, which was designed to compare first-line everolimus followed by sunitinib at progression with the standard sequence of first-line sunitinib followed by everolimus in metastatic RCC [62]. According to further genomic studies on RECORD-3 enrolled patients, KDM5C mutations were related to longer PFS (20.6 months) if compared to PBRM1 (11 months) and BAP1 mutations (8.1 months) among patients treated with firstline sunitinib, suggesting a role of these genetic abnormalities in granting VEGFR-targeted therapy sensibility. On the other side, PBMR1 alterations were associated with PFS benefits compared to BAP1 mutations (12.8 months vs. 4.9 months) in case of first-line treatment with everolimus [63].

However, even though the meta-analysis of ESPN and ASPEN pooled data did not display any significant difference in terms of PFS (HR 1.3, $p=0.15)$, a trend for superiority of sunitinib over everolimus was demonstrated, thus explaining the clinical recommendation preferring sunitinib over mTOR inhibitors [4]. This advantage of sunitinib in terms of survival benefits was recently reached when compared to temsirolimus, in a current phase IIa trial as well [64]. Moreover, the clinical activity of sunitinib in untreated patients with locally advanced or metastatic type 1 and type 2 pRCC was proved in a phase II SUPAP 
trial, despite being lower than in clear cell histotype (Table 2) [65]. To date there is no evidence supporting the use of the VEGF-aimed monoclonal antibody bevacizumab as monotherapy in nccRCC patients. Nevertheless, the combination of bevacizumab with everolimus appeared to have an encouraging clinical activity when used as a first-line strategy in advanced nccRCC patients, especially in case of papillary histotype as well as unclassified renal cancer with a major papillary component [66]. The biological rationale of this combination strategy is to be found in the MTOR pathway activation after the tumor hypoxia induced by VEGF-targeting treatments [67]. As for other VEFGR-targeted tyrosine kinase inhibitors, a small non-randomized trial supported the efficacy of sorafenib among papillary and chromophobe RCC patients, although it seemed to be limited if compared with sunitinib in the same setting [68]. Most of the data evaluating the efficacy of pazopanib in metastatic nccRCC derived from retrospective studies, pointing out its use as a possible therapeutic option in this setting. Since comparator trials are missing and prospective data are strictly limited, the administration of this latter TKI outside clinical trials is not routinely recommended [69].

\section{2. mTOR Pathway}

The protein kinase mTOR (mechanistic target of rapamycin) controls cell growth and its metabolism and it is usually assembled into several complexes such as mTOR complex $1 / 2(\mathrm{mTORC} 1 / 2)[70]$.

Even the mTOR signaling pathway has a relevant role in the development of kidney cancer and it represents an attractive therapeutic target among several subgroups of RCC. The activation of this axis provokes the upregulation of hypoxia-inducible factor $1 \alpha(\mathrm{HIF}-$ $1 \alpha$ ), a transcription factor that regulates the expression of various genes (VEGF among others) involved in adjusting mechanisms to hypoxia such as angiogenesis, apoptosis, or tumor metastasis [71].

Preliminary data about the efficacy of blocking HIF- $2 \alpha$ in heavily pretreated ccRCC emerged from a recent phase I study performed by Choueiri, in which the new compound belzutifan (MK-6482) showed a promising anti-tumor activity, with a good safety profile. It would be interesting to test belzutifan in new trials involving patients with nccRCC, to explore its potential role in this setting [72].

In Cowden disease, a hereditary autosomal dominant syndrome associated with germline mutation of PTEN, which is an onco-suppressor gene that inhibits the PI3K/Akt/ mTOR pathway, making it possible to develop clear cell, papillary, and chromophobe RCC [73]. Therefore, in this context, targeting mTOR represents an effective strategy and the same benefit could be achieved even in other genetic syndromes.

Tuberous sclerosis complex (TSC)-associated kidney cancer is another autosomal dominant syndrome characterized by different renal tumors (for example, angiomyolipoma and its malignant variant epithelioid angiomyolipoma) and caused by alterations in two genes, TSC1 and TSC2, that induce the constitutive activation of the LKB1/AMPK/TSC/mTOR pathway [74]. Positive results of EXIST-2 trial have led to the approbation of the mTOR inhibitor everolimus for the treatment of TSC-associated AML in many countries [75].

As far as autosomal dominant BHD syndrome, the most represented renal tumors are ccRCC, eosinophilic chromophobe RCC, oncocytoma, and hybrid oncocytic. FLCN is the tumor suppressor gene linked to the development of this pathology and its homozygous loss induces mTORC1 and 2 activation [76]. This molecular rationale justified the use of the inhibition of mTOR but further studies are needed to determine if this group of therapies provides benefit in patients with BHD-associated renal cell carcinoma [77].

In Xp11 translocation RCC, the mTOR and HIF- $1 \alpha$ pathway are normally upregulated, as demonstrated by the increased expression of the downstream molecule phosphorylated S6 [78]. A study published in December 2018 identified TFE3/IRS-1/PI3K/AKT/mTOR as a potential altered pathway in TFE3-tRCC and suggested a potential inhibition of this axis with a dual PI3K/mTOR inhibitor [79]. 
SDH-RCC (succinate dehydrogenase deficient RCC) and HLRCC (hereditary leiomyomatosis with RCC) reflect the Warburg-effect (preferential anaerobic glycolysis by the tumor's cells even in presence of oxygen) in renal cell carcinoma. The first-mentioned syndrome is a hereditary disease linked to the predisposition to aggressive type II papillary RCC and it is caused by the mutation of the gene that encodes FH, an enzyme involved in the Krebs cycle. This genetic alteration produces an accumulation of HIF- $1 \alpha$ that promotes the anaerobic glycolysis of the Warburg-effect [80]. Moreover, this syndrome is characterized by lower levels of AMPK and upregulation of mTOR pathway, representing a possible therapeutic target for this patient.

On the other hand, mutations of succinate dehydrogenase genes SCHD, SDHB, and SDHC represent the genetic hallmark of SDH-RCC [81]. This alteration induces increased levels of succinate with the subsequent HIF accumulation. In accordance with this biological evidence, targeting mTOR pathways or angiogenesis may reduce glucose uptake by tumor cells, interfering in this way with the proliferation of both these hereditary cancer diseases [82].

As regards the clinical efficacy in inhibiting mTOR in non-clear cell RCC, the phase II trial RAPTOR evaluated everolimus as first-line therapy in 92 treatment-naïve metastatic patients with papillary RCC, showing in the intention-to-treat (ITT) population a median PFS of 4.1 months (95\% CI 3.6-5.5) and median OS was 21.4 months (95\% CI 15.4-28.4) [83].

The subgroup analysis of the RAD001 Expanded Access Clinical Trial (REACT) demonstrated some benefit for everolimus: a PFS of 2.8 months and an ORR of $50.6 \%$, with $1.3 \%$ of PR and with $49.3 \%$ of patients that presented stable disease [84].

Another phase II trial revealed a PFS of 13.1 months in patients with chromophobe histotype versus 3.4 months in the other nccRCC subgroups $(p=0.084)$ [85].

Temsirolimus also documented a clinical benefit in patients with nccRCC, especially in the chromophobe histotype, [86] and provided more clinical benefit compared with interferon, regardless of renal tumor histology [87].

\subsection{MET Pathway}

As stated before, papillary RCC are closely linked to activating mutations of the MET proto-oncogene on chromosome 7q31 [19]. MET mesenchymal epithelial transition or hepatocyte growth factor receptor) gene encodes for the tyrosine kinase receptor of the hepatocyte growth factor (HGF), which is normally expressed on epithelial and endothelial cells plasma membrane. When it is bound by the inactive serine-protease analog HGF, this tyrosine kinase receptor causes the activation of RAS/MAPK and PI3K/AKT pathways, leading to the expression of multiple genes involved in several physiological functions, such as embryonic organogenesis or adult tissue regeneration, as well as pathological phenomena including tumor growth, malignant cell infiltration, and metastasis [88]. MET is shown to share signaling intermediates with the VEGFR axis. ERK, MAPK, AKT, and FAK may be activated by the MET/HGF axis as well as by VEGFR. Moreover, VEGFa expression and angiogenesis may be induced by the MET signaling pathway through SRC homology 2 domain-containing proteins (SHCs). The overexpression of hypoxiainduced factors HIF- $1 \alpha$ and HIF-1 $\beta$ results in MET expression as well [89]. In addition, the upregulation of the MET/HGF axis is linked to the acquired resistance to previous VEGFR-targeted therapies displayed in metastatic RCC patients [90].

Whereas activating mutations in MET proto-oncogene are commonly described in the germline of HPRCC patients [19], somatic MET alterations have a driver role in about 13-20\% of sporadic type 1 pRCCs [91]. As a consequence, the MET/HGF axis must be considered another pivotal therapeutic target in RCC, especially with regards to papillary nccRCCs. Among MET-directed inhibitory agents, we may keep in mind foretinib, tivantinib, crizotinib, but mostly cabozantinib and savolitinib. 
The final results of the SWOG-1500 phase II trial (also known as PAPMET) have been recently presented by Pal and colleagues at the American Society of Clinical Oncology Genito-urinary (ASCO GU) Cancers Symposium 2021 [92]. In this study, the clinical activity of the current standard-of-care sunitinib was compared to multi-kinase inhibitors cabozantinib, crizotinib, and savolitinib in 152 patients with metastatic pRCC (up to one prior systemic therapy was permitted). Cabozantinib was shown to reach the primary endpoint with a gain in terms of PFS (9.0 months) in comparison to sunitinib (5.6 months), regardless of the MET status (HR 0.60, 95\% CI 0.37-0.97; one-sided $p=0.019$ ). On the other side, the enrollment in the other two arms of savolitinib and crizotinib was stopped in advance on the basis of a preplanned futility analysis. These findings suggested a key role of both VEGF- and MET-signaling pathways in pRCC's oncogenesis, thereby explaining its higher responsiveness to a dual VEGF/MET inhibitor such as cabozantinib than to more selective MET inhibitors as crizotinib or savolitinib [92]. Therefore, cabozantinib may be considered as a novel practice changing strategy for metastatic pRCC patients (Table 2). Taking into account the noteworthy results of the recent phase III CheckMate 9ER trial in the metastatic clear cell setting, it would be of interest assessing the clinical activity of cabozantinib in combination with an ICI (such as the PD-L1 inhibitor atezolizumab in the ongoing COSMIC-021 and CONTACT-03 studies) for an even more effective management of pRCCs [93,94]. As for savolitinib, in a 2017 phase II study this selective MET-inhibitor unveiled promising activity in metastatic pRCC with MET-driven mutations (i.e., gains in chromosome 7, MET amplifications, HGF alterations, and so on) if compared to the MET-independent disease (median PFS was 6.2 months vs. 1.4 months, respectively; HR 0.33, 95\% CI: 0.20-0.52; $p$ < 0.001) [95]. Moreover, the 2020 phase III SAVOIR trial compared the administration of savolitinib to sunitinib in patients with advanced MET-driven pRCC (Table 2) [96]. Although this study did not meet its primary endpoint of PFS (HR 0.71; 95\% CI, 0.37-1.36; $p=0.31$ ) probably due to its design as well as the low accrual of patients, savolitinib was shown to achieve a significantly better response rate than sunitinib (ORR $27 \%$ vs. $7 \%$ ), along with a better safety profile [97]. Likewise, crizotinib might ensure more benefits if used in patients with metastatic pRCC characterized by MET-driven mutations. As a matter of fact, the CREATE trial highlighted the correlation between the administration of crizotinib and the higher response rate and long-lasting disease control in metastatic type 1 pRCC patients with MET-driven mutations, if compared to patients with MET-independent disease (Table 2) [98]. Further comparative studies designed with a genomically driven approach would be needed to better explore the activity of savolitinib and crizotinib in this setting.

Foretinib (a multi-kinase inhibitor targeting MET, VEGFR-2, RON, and AXL) was one of the first MET-targeted agents investigated, and it showed a promising clinical activity with a manageable safety profile in a multicenter phase II trial of patients with sporadic and hereditary pRCC. The preplanned subgroup analysis unveiled a higher response rate obtained with foretinib in patients with germline MET-driven mutations than in patients without these genetic alterations [99]. Conversely, the selective MET-inhibitor tivantinib, either alone or in combination with EGFR-inhibitor erlotinib, displayed no clinical activity among patients with advanced pRCC (Table 2) [100].

The involvement of the MET/HGF axis is also related to non-papillary nccRCC's oncogenesis. For example, the aberrant ASPL-TFE3 fusion protein in MiT family translocation RCC seems to induce the overexpression of $M E T$ proto-oncogene by binding its promoter region, leading to $\mathrm{MET}$ autophosphorylation and activation of downstream signaling in the presence of HGF [101]. Nevertheless, available data regarding the use of tivantinib in patients with MiT family translocation RCCs pointed out neither survival benefits nor promising response rates related to this TKI [102]. 
Table 2. Tyrosine kinase inhibitors assessed in pRCC: recent published trials.

\begin{tabular}{|c|c|c|c|c|c|c|c|}
\hline Trials & Histologies & Drug & Setting & N. of Patients & ORR (\%) & $\begin{array}{c}\text { mOS } \\
\text { (Months) }\end{array}$ & $\begin{array}{c}\text { mPFS } \\
\text { (Months) }\end{array}$ \\
\hline $\begin{array}{c}\text { SWOG } \\
\text { 1500/PAPMET } \\
\text { (phase II) } \\
\text { [92] }\end{array}$ & pRCC & $\begin{array}{l}\text {-cabozantinib } \\
\text {-sunitinib } \\
\text {-savolitinib } \\
\text {-crizotinib }\end{array}$ & $\begin{array}{l}\text { First or second } \\
\text { line }\end{array}$ & $\begin{array}{l}-44 \\
-46 \\
-29 \\
-28\end{array}$ & $\begin{array}{l}-23 \\
-4 \\
-3 \\
-0\end{array}$ & $\begin{array}{l}-20.4 \\
-16.4 \\
-11.7 \\
-19.9\end{array}$ & $\begin{array}{c}9.0 \\
-5.6 \\
-3.0 \\
-2.8\end{array}$ \\
\hline $\begin{array}{c}\text { SAVOIR } \\
\text { (phase III) } \\
\text { [96] }\end{array}$ & $\mathrm{pRCC}$ & $\begin{array}{l}\text {-savolitinib } \\
\text {-sunitinib }\end{array}$ & $\begin{array}{l}\text { First or later } \\
\text { line }\end{array}$ & $\begin{array}{l}-33 \\
-27\end{array}$ & $\begin{array}{l}-27 \\
-7 \\
\end{array}$ & $\begin{array}{l}-\mathrm{NR} \\
-13.2\end{array}$ & $\begin{array}{l}-7.0 \\
-5.6 \\
\end{array}$ \\
\hline $\begin{array}{c}\text { SUPAP } \\
\text { (phase II) } \\
\text { [65] }\end{array}$ & $\begin{array}{l}\text { pRCC: } \\
\text {-type } 1 \\
\text {-type } 2\end{array}$ & -sunitinib & First line & $\begin{array}{l}-15 \\
-46\end{array}$ & $\begin{array}{l}-13 \\
-11\end{array}$ & $\begin{array}{l}-17.8 \\
-12.4\end{array}$ & $\begin{array}{l}-6.6 \\
-5.5\end{array}$ \\
\hline $\begin{array}{c}\text { CREATE (phase } \\
\text { II) } \\
\text { [98] }\end{array}$ & $\begin{array}{c}\text { pRCC: } \\
\text {-type } 1 \\
\text {-MET-driven } \\
\text { type1 } \\
\text {-MET- } \\
\text { independent } \\
\text { type1 }\end{array}$ & -crizotinib & $\begin{array}{l}\text { First or later } \\
\text { line }\end{array}$ & $\begin{array}{l}-23 \\
-4 \\
-19\end{array}$ & $\begin{array}{l}-17 \\
-50 \\
-11\end{array}$ & $\begin{array}{l}-30.5 \\
-\mathrm{NA} \\
-14.5\end{array}$ & $\begin{array}{l}-5.8 \\
-\mathrm{NA} \\
-3.0\end{array}$ \\
\hline $\begin{array}{c}\text { SWOG S1107 } \\
\text { (phase II) } \\
{[100]}\end{array}$ & $\mathrm{pRCC}$ & $\begin{array}{c}\text {-tivantinib } \\
\text {-tivantinib + } \\
\text { erlotinib }\end{array}$ & $\begin{array}{l}\text { First or second } \\
\text { line }\end{array}$ & $\begin{array}{l}-25 \\
-25 \\
\end{array}$ & $\begin{array}{l}-0 \\
-0 \\
\end{array}$ & $\begin{array}{l}-10.3 \\
-11.3 \\
\end{array}$ & $\begin{array}{l}-2.0 \\
-3.9 \\
\end{array}$ \\
\hline $\begin{array}{c}\text { NCT00726323 } \\
\text { (phase II) } \\
\text { [99] }\end{array}$ & $\mathrm{pRCC}$ & -foretinib & $\begin{array}{l}\text { First or second } \\
\text { line }\end{array}$ & 74 & 13.5 & NA & 9.3 \\
\hline $\begin{array}{c}\text { NCT02127710 } \\
\text { (phase II) }\end{array}$ & $\begin{array}{c}\text {-pRCC } \\
\text {-MET-driven } \\
\text { pRCC } \\
\text {-MET- } \\
\text { independent } \\
\text { pRCC }\end{array}$ & -savolitinib & $\begin{array}{l}\text { First or later } \\
\text { line }\end{array}$ & $\begin{array}{l}-109 \\
-44 \\
-65\end{array}$ & $\begin{array}{c}-7 \\
-18 \\
-0\end{array}$ & $\begin{array}{l}\text {-NA } \\
\text {-NA } \\
\text {-NA }\end{array}$ & $\begin{array}{l}-\mathrm{NA} \\
-6.2 \\
-1.4\end{array}$ \\
\hline
\end{tabular}

Abbreviations: $\mathrm{pRCC}=$ papillary renal cell carcinoma; $\mathrm{NA}=$ not available; $\mathrm{NR}=$ not reached; $\mathrm{ORR}=$ overall response rate; $\mathrm{mPFS}=$ median progression-free survival; $\mathrm{mOS}=$ median overall survival.

\section{Immunotherapy and New Therapeutic Perspectives in nccRCC}

As shown in several recent trials, RCC is a tumor with a mild to high percentage of somatic mutations, leading to an overexpression of neoantigens and then to a high immunogenic power. As a proof of it, renal cancer is characterized by a dysfunctional immune cell infiltrate along with an immune suppressive microenvironment [103-105]. Cancer-induced immune suppression is one of the most effective strategies that allows tumor growth. Notably, this tumoral "immune escape" is mostly mediated by programmed death protein-1 (PD-1) and cytotoxic T-lymphocyte associated antigen-4 (CTLA4), which are expressed on T cells' plasmalemma and may trigger inhibitory pathways blocking the anti-cancer immune response, thus explaining the revolutionary use of anti-PD-1/PDL1 and anti-CTLA-4 agents in several tumors. Thanks to more detailed studies, it was pointed out that many other strategies pursue the same results [89]. In 2017, Chen et al. described three basic immune profiles that might be related to patients' response to antiPD-L1/PD-1 therapy. Whereas the "immune desert" tumors are characterized by the total lack of intratumoral immune cell infiltration (because of immunological ignorance, induction of tolerance or absence of appropriate T-cell priming), the "immune excluded" tumors exploit many strategies to hide from immune response, such as the development of angiogenesis and extracellular matrix. Lastly, the "inflamed" tumors are characterized by a rich intratumoral infiltrate of CD8+ and CD4+ T-lymphocytes, along with myeloid and monocytic cells, that are restrained by the above-mentioned "immune escape" mechanisms. The latter profile may be the result of a pre-existing antitumor immune response that was arrested, probably by immunosuppression in the malignant microenvironment [106]. 
This "immune escape" strategy appears to be linked to no single gene alterations. Otherwise, the most plausible hypothesis is that this escape is due to different mutated genes which cooperate with each other. With regards to renal cancers, the Cancer Genome Atlas molecular characterization of RCCs carried out a comprehensive immune signature gene profiling demonstrating that, with the exception of Th17 (mostly characterizing chRCC), IL-8 and CD56 ${ }^{\text {bright }} \mathrm{NK}$ (more expressed in pRCCs) cell genes, the others were more significantly overexpressed in ccRCC than pRCC and chRCC [107]. Furthermore, the Th2 gene signature (related to T-lymphocyte regulatory activity) was shown to be significantly upregulated in most of cCRCC, in all pRCC with a CpG island methylator phenotype (also known as CIMP-pRCC), and in some pRCC and chRCC; this signature may be considered a negative prognostic factor, regardless of tumor histologies [107]. The TCGA also noticed that ccRCC maximally expresses specific genes such as PDCD1 and CD247 (coding for PD1 and PD-L1), in comparison to pRCC and chRCC [107]. In addition, immune inflamed tumors were described to be lacking PBRM1 alterations, being characterized by chromosomal losses of 9p21.3 instead. Whereas the PBRM1 wild type seems to positively influence patients' response to anti-PD-1 treatments, losses of 9p21.3 appear to be related to a worse outcome with PD-1 inhibitors. Nonetheless, tumor mutation burden, neoantigen overexpression, and HLA zygosity were not associated with higher anti-PD-1 therapy sensibility [108].

As stated before, the improvement in "immune escape" knowledge has led researchers to investigate novel treatment approaches for patients with advanced RCC using PD1/PD-L1- and CTLA-4-targeted ICIs. While the immunotherapy has been assessed in ccRCC since 2015 [109], the first promising data about non-clear cell histologies have been recently highlighted in the 2021 phase II KEYNOTE 427 trial [110]. The KEYNOTE 427 trial investigated the efficacy and safety of the anti-PD-1 pembrolizumab as monotherapy for untreated patients with advanced ccRCC (cohort A) and advanced nccRCC (cohort B). Focusing on cohort B patients, first-line pembrolizumab showed promising clinical activity (ORR 26.7\%) in the overall nccRCC population, regardless of International Metastatic RCC Database Consortium (IMDC) risk groups, and granted consistent results in selected patient subgroups with tumors with high PD-L1 expression [110]. When evaluated by RCC histology, response rates were higher for patients with papillary and unclassified RCC than for patients with chRCC [110]. Given the better survival traditionally related to the chromophobe histotype, further studies are necessary to explain this unclear finding.

Lee and colleagues have recently presented the primary results of the use of the nivolumab + cabozantinib combination in metastatic nccRCC patients, at the American Society of Clinical Oncology (ASCO) Symposium 2021 [111]. This phase II study (NCT03635892) tested the administration of nivolumab and cabozantinib in treatment-naïve, or previously treated with one VEGF-R TKI or mTOR inhibitor, patients with pRCC, MiT family translocation RCC, unclassified RCC (cohort 1), or chRCC (cohort 2). The above-mentioned immunocombination showed an acceptable safety profile along with a promising clinical efficacy in all the histologies included in the cohort 1. Considering a 13.1-month long median follow-up, cohort 1 patients witnessed a median PFS of 12.5 months (95\% CI: 6.3-16.4) and a median OS of 28 months (95\% CI: 16.3-NE). The primary endpoint ORR for cohort 1 was $48 \%$ (95\% CI: 31.5-63.9). On the other hand, no response emerged in the chromophobe subtype (ORR for cohort 2 was $0 \%$ ), confirming the poor clinical efficacy of ICI-based regimens in chRCC already highlighted in the KEYNOTE 427 trial. 
Several trials are currently underway assessing the activity of ICIs in non-clear cell histotypes, such as UNISoN (NCT03177239) and SUNIFORECAST (NCT03075423), which are investigating the use of nivolumab with or without ipilimumab in nccRCC patients. Furthermore, promising preliminary data have recently been obtained with regards to the coadministration of bevacizumab and atezolizumab among nccRCC patients (NCT02724878) [112] or the combination of savolitinib and durvalumab in pRCC (NCT02819596, CALYPSO trial) [113]. The phase III CONTACT-03 trial is currently evaluating the efficacy of atezolizumab plus cabozantinib in patients with advanced nccRCC progressed after an ICIbased first-line therapy (NCT04338269). Promising preliminary results come from other ongoing studies testing cabozantinib in combination with atezolizumab (COSMIC-021, NCT03170960) or with nivolumab and ipilimumab (COSMIC-313, NCT03937219) [114,115]. Additionally, the phase II KEYNOTE-B61 trial is currently testing the coadministration of anti-PD-1 pembrolizumab with TKI lenvatinib as first-line strategy among metastatic nccRCC patients (NCT04704219) [116].

It must be considered noteworthy the significant ICI-based regimens' antitumor activity in RCC with sarcomatoid and rhabdoid features (S/R RCC), whose response to classic RCC treatments (including anti-angiogenic agents as well as mTOR inhibitors) is poor [117]. As highlighted in the up-to-date work by Bakouny and colleagues, S/R RCCs harbor a significantly high rate of distinctive genomic alterations that lead to the development of an "inflamed" phenotype, thereby supporting their response to ICIs. A significant clinical benefit has been noticed for patients with S RCC treated with first-line ICI-based regimens, as pointed out in four large clinical trials in which these combinations were compared to sunitinib (CheckMate 214, JAVELIN Renal 101, IMmotion151, and KEYNOTE 426) [118-121]. Lastly, in an exploratory subgroup analysis of 75 patients with sarcomatoid features of the CheckMate 9ER trial, nivolumab + cabozantinib displayed a reduction of $64 \%$ of death risk compared to sunitinib (HR 0.36; 95\% CI: $0.17-0.79$ ), and an ORR of $55.9 \%$ vs. $22.0 \%$ [122]. In Table 3 we report the most relevant published and underway phase II/III trials, testing the clinical activity of ICI-based regimens in nonclear cell disease. In Table 4 we display the results of phase III pivotal studies assessing immuno-combinations in mRCC with regards to $S$ RCC subgroups.

As emerged from these data, our knowledge about the interaction between RCC and the immune system is in constant development. Indeed, several novel strategies are emerging for the management of RCC and are in the course of investigation. Among these, strategies of certain interest include the use of CIK cells (a heterogeneous population of effector CD3+CD56+ NK T cells) combined with the anti-PD-1 drug camrelizumab (NCT03987698) and the chance to combine polyethylene glycolylated IL-2 (NKTR-214) to VB10.NEO, an individualized DNA plasmid cancer vaccine [123]. Furthermore, a new class of promising compounds, currently under investigation in multiple human cancers in the context of in vivo and in vitro experiments, are the SOD mimics. Mostly in RCC, the importance of oxidative stress has been widely demonstrated. MnP (MnTnHex-2-PyP5+), one of these molecules, has been studied in an in vitro experimentation performed on 786-O cells (a human cell line derived from primary clear-cell adenocarcinoma from a male patient). MnP showed a certain cytotoxic activity and the enhancement of intracellular ROS, suggesting its potential role in reducing the migration of renal cancer cells. Clearly, further studies about this and other SOD mimic compounds are needed to better analyze their potential function in treating clear cell and non-clear cell RCC [124]. 
Table 3. A summary of the main published and ongoing phase II and III studies evaluating immunotherapies in non-clear cell histotypes.

\begin{tabular}{|c|c|c|c|c|}
\hline Clinical Trial (phase) & Experimental Arm & Histology & Setting & Primary Endpoint \\
\hline $\begin{array}{l}\text { KEYNOTE } 427 \\
\text { (phase II) [110] }\end{array}$ & Pembrolizumab & $\begin{array}{c}\text { pRCC type } 1 \text { and } 2, \\
\text { chRCC, unclassified } \\
\text { nccRCC }\end{array}$ & $\begin{array}{c}\text { Previously untreated } \\
\text { metastatic ccRCC } \\
\text { (cohort A) and nccRCC } \\
\text { (cohort B) }\end{array}$ & $\begin{array}{l}\text { ORR }(26.7 \% \text { in the } \\
\text { overall nccRCC } \\
\text { population })\end{array}$ \\
\hline $\begin{array}{l}\text { NCT03635892 } \\
\text { (phase II) [111] }\end{array}$ & $\begin{array}{l}\text { Nivolumab + } \\
\text { cabozantinib }\end{array}$ & $\begin{array}{l}\text { pRCC type } 1 \text { and 2, } \\
\text { chRCC, MiT family } \\
\text { translocation RCC, } \\
\text { unclassified nccRCC }\end{array}$ & $\begin{array}{l}\text { Previously untreated or } \\
\text { treated with a prior } \\
\text { VEGF-R TKI/mTORi } \\
\text { metastatic pRCC, MiT } \\
\text { family translocation } \\
\text { RCC, unclassified RCC } \\
\text { (cohort } 1 \text { ) and chRCC } \\
\text { (cohort } 2 \text { ) }\end{array}$ & $\begin{array}{l}\text { ORR }(48 \% \text { in cohort } 1, \\
0 \% \text { in cohort } 2)\end{array}$ \\
\hline $\begin{array}{l}\text { CONTACT-03 } \\
\text { (phase III) }\end{array}$ & $\begin{array}{l}\text { Atezolizumab + } \\
\text { cabozantinib }\end{array}$ & $\begin{array}{l}\text { All non-clear cell } \\
\text { subtypes }\end{array}$ & $\begin{array}{l}\text { Locally advanced or } \\
\text { metastatic RCC in PD } \\
\text { during or after one } \\
\text { ICI-based regimen }\end{array}$ & $\begin{array}{c}\text { PFS and OS (no results } \\
\text { posted, recruiting } \\
\text { underway) }\end{array}$ \\
\hline $\begin{array}{c}\text { COSMIC-021 } \\
\text { (phase Ib/II) [114] }\end{array}$ & $\begin{array}{l}\text { Atezolizumab + } \\
\text { cabozantinib }\end{array}$ & $\begin{array}{l}\text { All non-clear cell } \\
\text { subtypes }\end{array}$ & $\begin{array}{l}\text { Previously untreated } \\
\text { locally advanced, } \\
\text { metastatic, or recurrent } \\
\text { solid tumors (including } \\
\text { ccRCC and nccRCC) }\end{array}$ & ORR (no results posted) \\
\hline $\begin{array}{l}\text { COSMIC-313 } \\
\text { (phase III) [115] }\end{array}$ & $\begin{array}{l}\text { Nivolumab + } \\
\text { ipilimumab + } \\
\text { cabozantinib }\end{array}$ & $\begin{array}{l}\text { All non-clear cell } \\
\text { subtypes }\end{array}$ & $\begin{array}{l}\text { Previously untreated } \\
\text { IMDC intermediate- } \\
\text { /poor-risk metastatic } \\
\text { RCC (including ccRCC } \\
\text { and nccRCC) }\end{array}$ & PFS (no results posted) \\
\hline
\end{tabular}

\begin{tabular}{|c|c|c|c|c|}
\hline $\begin{array}{l}\text { UNISoN } \\
\text { (phase II) }\end{array}$ & $\begin{array}{c}\text { Nivolumab (for a } \\
\text { maximum of } 12 \\
\text { months), then } \\
\text { nivolumab }+ \\
\text { ipilimumab ( } 4 \text { cycles) } \\
\text { and lastly maintenance } \\
\text { with nivolumab } \\
\text { single agent }\end{array}$ & $\begin{array}{l}\text { pRCC type } 1 \text { and type } \\
\text { 2, chRCC, S RCC, Xp11 } \\
\text { translocation RCC, } \\
\text { unclassified nccRCC }\end{array}$ & $\begin{array}{l}\text { Metastatic nccRCC } \\
\text { previously untreated or } \\
\text { treated with a VEGF-R } \\
\text { TKI or another } \\
\text { systemic therapy }\end{array}$ & ORR (no results posted) \\
\hline $\begin{array}{l}\text { SUNIFORECAST } \\
\text { (phase II) }\end{array}$ & $\begin{array}{l}\text { Nivolumab + } \\
\text { ipilimumab }\end{array}$ & $\begin{array}{l}\text { All non-clear cell } \\
\text { subtypes }\end{array}$ & $\begin{array}{l}\text { Previously untreated } \\
\text { locally advanced or } \\
\text { metastatic nccRCC }\end{array}$ & OS (no results posted) \\
\hline $\begin{array}{c}\text { CALYPSO } \\
\text { (phase } \mathrm{Ib} / \mathrm{II}) \text { [113] }\end{array}$ & $\begin{array}{l}\text { Savolitinib + } \\
\text { durvalumab }\end{array}$ & pRCC type 1 and type 2 & $\begin{array}{c}\text { Previously untreated } \\
\text { metastatic ccRCC } \\
\text { (cohort A) and nccRCC } \\
\text { (cohort B) }\end{array}$ & $\begin{array}{l}\text { DLT, ORR (no results } \\
\text { posted) }\end{array}$ \\
\hline $\begin{array}{l}\text { NCT02724878 } \\
\text { (phase II) [112] }\end{array}$ & $\begin{array}{l}\text { Atezolizumab + } \\
\text { bevacizumab }\end{array}$ & $\begin{array}{l}\text { All non-clear cell } \\
\text { subtypes }\end{array}$ & $\begin{array}{l}\text { Previously untreated } \\
\text { locally advanced or } \\
\text { metastatic nccRCC }\end{array}$ & $\begin{array}{c}\text { ORR }(33 \% \text { in the } \\
\text { experimental group) }\end{array}$ \\
\hline $\begin{array}{l}\text { KEYNOTE-B61 } \\
\text { (phase II) [116] }\end{array}$ & $\begin{array}{c}\text { Pembrolizumab }+ \\
\text { lenvatinib }\end{array}$ & $\begin{array}{l}\text { All non-clear cell } \\
\text { subtypes }\end{array}$ & $\begin{array}{l}\text { Previously untreated } \\
\text { locally advanced or } \\
\text { metastatic nccRCC }\end{array}$ & $\begin{array}{l}\text { ORR (no results posted, } \\
\text { recruiting underway) }\end{array}$ \\
\hline
\end{tabular}

Abbreviations: pRCC = papillary renal cell carcinoma; chRCC = chromophobe renal cell carcinoma; nccRCC = non-clear cell renal cell carcinoma; ccRCC = clear cell renal cell carcinoma; $\mathrm{S}$ RCC $=$ renal cell carcinoma with sarcomatoid features; ORR = overall response rate; $\mathrm{PFS}=$ progression-free survival; $\mathrm{OS}=$ overall survival; $\mathrm{DLT}=$ dose limiting toxicity; $\mathrm{PD}=$ disease progression; $\mathrm{ICI}=\mathrm{immune}$ checkpoint inhibitor; VEGF-R TKI = vascular endothelial growth factor receptor's tyrosine kinase inhibitor; $\mathrm{mTORi}=\mathrm{mTOR}$ inhibitor; IMDC = International Metastatic RCC Database Consortium. 
$\mathrm{y}$

Table 4. Survival outcomes and antitumor activity of ICI-based regimens among RCC with sarcomatoid features.

\begin{tabular}{|c|c|c|c|c|}
\hline & $\begin{array}{c}\text { CheckMate 9ER } \\
\text { [122] }\end{array}$ & $\begin{array}{c}\text { KEYNOTE } 426 \\
{[121]}\end{array}$ & $\begin{array}{c}\text { Javelin RENAL } 101 \\
\text { [119] }\end{array}$ & $\begin{array}{c}\text { CheckMate } 214 \\
\text { [118] }\end{array}$ \\
\hline Experimental arm & $\begin{array}{l}\text { Nivolumab + } \\
\text { cabozantinib }\end{array}$ & $\begin{array}{l}\text { Pembrolizumab + } \\
\text { axitinib }\end{array}$ & Avelumab + axitinib & $\begin{array}{l}\text { Nivolumab + } \\
\text { ipilimumab }\end{array}$ \\
\hline $\begin{array}{c}\text { mOS } \\
\text { (months) }\end{array}$ & $\begin{array}{c}\text { NR }(95 \% \text { CI, 22.8-NE) } \\
\text { HR 0.36 (95\% CI, } \\
0.17-0.79)\end{array}$ & $\begin{array}{c}\mathrm{NR} \\
\text { HR } 0.58(95 \% \mathrm{CI}, \\
0.21-1.59)\end{array}$ & Data unavailable & $\begin{array}{c}\text { NR }(95 \% \text { CI, 25.2-NE) } \\
\text { HR 0.45 (95\% CI, } \\
0.30-0.70)\end{array}$ \\
\hline $\begin{array}{c}\text { mPFS } \\
\text { (months) }\end{array}$ & $\begin{array}{c}10.3(95 \% \text { CI, 5.6-19.4) } \\
\text { HR 0.42 (95\% CI, } \\
0.23-0.74)\end{array}$ & $\begin{array}{c}\mathrm{NR} \\
\text { HR } 0.54(95 \% \mathrm{CI}, \\
0.29-1.00)\end{array}$ & $\begin{array}{c}7.0(95 \% \text { CI, 5.3-13.8) } \\
\text { HR 0.57 (95\% CI, } \\
0.325-1.003)\end{array}$ & $\begin{array}{c}26.5 \\
\text { HR 0.54 (95\% CI, } \\
0.33-0.86)\end{array}$ \\
\hline $\begin{array}{l}\text { ORR } \\
\text { (CR) }\end{array}$ & $\begin{array}{c}55.9 \% \\
\text { (CR unavailable) }\end{array}$ & $\begin{array}{l}58.8 \% \\
(13 \%)\end{array}$ & $\begin{array}{l}46.8 \% \\
(4.3 \%)\end{array}$ & $\begin{array}{c}60.8 \% \\
(18.9 \%)\end{array}$ \\
\hline
\end{tabular}

Abbreviations: $\mathrm{ORR}=$ overall response rate; $\mathrm{CR}=$ complete response rate; $\mathrm{mPFS}=$ median progression-free survival; $\mathrm{mOS}=$ median overall survival; ICI = immune checkpoint inhibitor; $\mathrm{NR}=$ not reached; $\mathrm{NE}=$ not estimable.

\section{Conclusions}

nccRCC comprises a wide diversity of histologies with different molecular alterations and prognosis. The knowledge on the genetic features guiding the development and progression of the different subtypes is expanding through molecular based analysis thus leading to a widening of the therapeutic scenario.

Open issues that need to be solved are the validation of biomarkers for early prediction of RCC progression, monitoring and response to treatment [3]. An improvement in this field could also lead to a better tailored management.

In addition, another unmet clinical need is to define the best treatment sequence, taking into account the promising results of the PAPMET trial, CheckMate 9ER, and also considering what might emerge from the other ongoing studies [125]. In particular, a great response to nivolumab plus cabozantinib has been highlighted in sarcomatoid RCC, changing the practice of these poor prognosis tumors.

Despite these encouraging results, it is still hard to enroll a significant number of patients in large prospective randomized clinical trials (also because of the rarity of the histological subtypes of nccRCC), which are necessary to answer all these questions.

Author Contributions: Conceptualization, F.M., A.M. and M.R.; writing—original draft preparation, A.M. and M.R.; data acquisition, analysis, interpretation, V.M., A.R., E.T. and G.N.; writing-review and editing, A.C., M.F. and M.S.; supervision, R.M. and F.M. All authors have read and agreed to the published version of the manuscript.

Funding: This research received no external funding.

Institutional Review Board Statement: Not applicable.

Informed Consent Statement: Not applicable.

Data Availability Statement: Not applicable.

Conflicts of Interest: The authors declare no conflict of interest.

\section{References}

1. Siegel, R.L.; Miller, K.D.; Jemal, A. Cancer statistics, 2020. CA Cancer J. Clin. 2020, 70, 7-30. [CrossRef] [PubMed]

2. Thompson, R.H.; Ordonez, M.A.; Iasonos, A.; Secin, F.P.; Guillonneau, B.; Russo, P.; Touijer, K. Renal Cell Carcinoma in Young and Old Patients-Is There a Difference? J. Urol. 2008, 180, 1262-1266. [CrossRef]

3. Marchioni, M.; Rivas, J.G.; Autran, A.; Socarras, M.; Albisinni, S.; Ferro, M.; Schips, L.; Scarpa, R.M.; Papalia, R.; Esperto, F. Biomarkers for Renal Cell Carcinoma Recurrence: State of the Art. Curr. Urol. Rep. 2021, 22, 1-7. [CrossRef]

4. Ahrens, M.; Scheich, S.; Hartmann, A.; Bergmann, L. IAG-N Interdisciplinary Working Group Kidney Cancer of the German Cancer Society Non-Clear Cell Renal Cell Carcinoma-Pathology and Treatment Options. Oncol. Res. Treat. 2019, 42, 128-135. [CrossRef] 
5. Moch, H.; Cubilla, A.L.; Humphrey, P.A.; Reuter, V.E.; Ulbright, T.M. The 2016 WHO Classification of Tumours of the Urinary System and Male Genital Organs-Part A: Renal, Penile, and Testicular Tumours. Eur. Urol. 2016, 70, 93-105. [CrossRef]

6. Hsieh, J.J.; Purdue, M.P.; Signoretti, S.; Swanton, C.; Albiges, L.; Schmidinger, M.; Heng, D.Y.; Larkin, J.; Ficarra, V. Renal cell carcinoma. Nat. Rev. Dis. Prim. 2017, 3, 1-19. [CrossRef] [PubMed]

7. Albiges, L.; Flippot, R.; Rioux-Leclercq, N.; Choueiri, T.K. Non-Clear Cell Renal Cell Carcinomas: From Shadow to Light. J. Clin. Oncol. 2018, 36, 3624-3631. [CrossRef]

8. Lopez-Beltran, A.; Scarpelli, M.; Montironi, R.; Kirkali, Z. 2004 WHO Classification of the Renal Tumors of the Adults. Eur. Urol. 2006, 49, 798-805. [CrossRef]

9. Rizzo, A.; Rosellini, M.; Marchetti, A.; Mollica, V.; Massari, F. Determinants of treatment for first-line immune-based combinations in metastatic renal cell carcinoma: A critical overview of recent evidence. Immunotherapy 2021, 13, 685-692. [CrossRef]

10. Zhang, T.; Gong, J.; Maia, M.C.; Pal, S.K. Systemic Therapy for Non-Clear Cell Renal Cell Carcinoma. Am. Soc. Clin. Oncol. Educ. Book 2017, 37, 337-342. [CrossRef] [PubMed]

11. Linehan, W.M.; Ricketts, C.J. The Cancer Genome Atlas of renal cell carcinoma: Findings and clinical implications. Nat. Rev. Urol. 2019, 16, 539-552. [CrossRef]

12. Ciccarese, C.; Massari, F.; Santoni, M.; Heng, D.Y.; Sotte, V.; Brunelli, M.; Conti, A.; Cheng, L.; Lopez-Beltran, A.; Scarpelli, M.; et al. New molecular targets in non clear renal cell carcinoma: An overview of ongoing clinical trials. Cancer Treat. Rev. 2015, 41, 614-622. [CrossRef] [PubMed]

13. Klatte, T.; Said, J.W.; Seligson, D.B.; Rao, P.N.; De Martino, M.; Shuch, B.; Zomorodian, N.; Kabbinavar, F.F.; Belldegrun, A.S.; Pantuck, A.J. Pathological, Immunohistochemical and Cytogenetic Features of Papillary Renal Cell Carcinoma With Clear Cell Features. J. Urol. 2011, 185, 30-36. [CrossRef] [PubMed]

14. Cancer Genome Atlas Research Network; Linehan, W.M.; Spellman, P.T.; Ricketts, C.J.; Creighton, C.J.; Fei, S.S.; Davis, C.; Wheeler, D.A.; Murray, B.A.; Schmidt, L.; et al. Comprehensive Molecular Characterization of Papillary Renal-Cell Carcinoma. N. Engl. J. Med. 2016, 374, 135-145. [CrossRef]

15. Yamashita, S.; Ioritani, N.; Oikawa, K.; Aizawa, M.; Endoh, M.; Arai, Y. Morphological subtyping of papillary renal cell carcinoma: Clinicopathological characteristics and prognosis. Int. J. Urol. 2007, 14, 679-683. [CrossRef] [PubMed]

16. Wong, E.; Di Lena, R.; Breau, R.H.; Pouliot, F.; Finelli, A.; Lavallée, L.T.; So, A.; Tanguay, S.; Fairey, A.; Rendon, R.; et al. Morphologic subtyping as a prognostic predictor for survival in papillary renal cell carcinoma: Type 1 vs. type 2 . Urol. Oncol. Semin. Orig. Investig. 2019, 37, 721-726. [CrossRef] [PubMed]

17. Pignot, G.; Elie, C.; Conquy, S.; Vieillefond, A.; Flam, T.; Zerbib, M.; Debré, B.; Amsellem-Ouazana, D. Survival Analysis of 130 Patients with Papillary Renal Cell Carcinoma: Prognostic Utility of Type 1 and Type 2 Subclassification. Urology 2007, 69, 230-235. [CrossRef] [PubMed]

18. Zhao, J.; Eyzaguirre, E. Clear Cell Papillary Renal Cell Carcinoma. Arch. Pathol. Lab. Med. 2019, 143, 1154-1158. [CrossRef] [PubMed]

19. Schmidt, L.; Duh, F.-M.; Chen, F.; Kishida, T.; Glenn, G.; Choyke, P.; Scherer, S.W.; Zhuang, Z.; Lubensky, I.; Dean, M.; et al. Germline and somatic mutations in the tyrosine kinase domain of the MET proto-oncogene in papillary renal carcinomas. Nat. Genet. 1997, 16, 68-73. [CrossRef]

20. Cimadamore, A.; Massari, F.; Santoni, M.; Mollica, V.; Di Nunno, V.; Cheng, L.; López-Beltrán, A.; Scarpelli, M.; Montironi, R.; Moch, H. Molecular characterization and diagnostic criteria of renal cell carcinoma with emphasis on liquid biopsies. Expert Rev. Mol. Diagn. 2019, 20, 141-150. [CrossRef]

21. Kovac, M.; Navas, C.; Horswell, S.; Salm, M.; Bardella, C.; Rowan, A.; Stares, M.; Castro-Giner, F.; Fisher, R.; De Bruin, E.C.; et al. Recurrent chromosomal gains and heterogeneous driver mutations characterise papillary renal cancer evolution. Nat. Commun. 2015, 6, 6336. [CrossRef]

22. Trpkov, K.; Hes, O.; Agaimy, A.; Bonert, M.; Martinek, P.; Magi-Galluzzi, C.; Kristiansen, G.; Lüders, C.; Nesi, G.; Compérat, E.; et al. Fumarate Hydratase-deficient Renal Cell Carcinoma Is Strongly Correlated With Fumarate Hydratase Mutation and Hereditary Leiomyomatosis and Renal Cell Carcinoma Syndrome. Am. J. Surg. Pathol. 2016, 40, 865-875. [CrossRef] [PubMed]

23. Pal, S.K.; Ali, S.M.; Yakirevich, E.; Geynisman, D.M.; Karam, J.A.; Elvin, J.A.; Frampton, G.M.; Huang, X.; Lin, D.I.; Rosenzweig, M.; et al. Characterization of Clinical Cases of Advanced Papillary Renal Cell Carcinoma via Comprehensive Genomic Profiling. Eur. Urol. 2018, 73, 71-78. [CrossRef] [PubMed]

24. Rini, B.I.; Campbell, S.C.; Escudier, B. Renal cell carcinoma. Lancet 2009, 28, 1119-1132. [CrossRef]

25. Garje, R.; Elhag, D.; Yasin, H.A.; Acharya, L.; Vaena, D.; Dahmoush, L. Comprehensive review of chromophobe renal cell carcinoma. Crit. Rev. Oncol. 2021, 160, 103287. [CrossRef] [PubMed]

26. Montironi, R.; Cimadamore, A.; Ohashi, R.; Cheng, L.; Scarpelli, M.; Lopez-Beltran, A.; Moch, H. Chromophobe Renal Cell Carcinoma Aggressiveness and Immuno-oncology Therapy: How to Distinguish the Good One from the Bad One. Eur. Urol. Oncol. 2021, 4, 331-333. [CrossRef] [PubMed]

27. Casuscelli, J.; Becerra, M.F.; Seier, K.; Manley, B.J.; Benfante, N.; Redzematovic, A.; Stief, C.G.; Hsieh, J.J.; Tickoo, S.K.; Reuter, V.E.; et al. Chromophobe Renal Cell Carcinoma: Results From a Large Single-Institution Series. Clin. Genitourin. Cancer 2019, 17, 373-379.e4. [CrossRef]

28. Davis, C.F.; Ricketts, C.J.; Wang, M.; Yang, L.; Cherniack, A.D.; Shen, H.; Buhay, C.; Kang, H.; Kim, S.C.; Fahey, C.C.; et al. The Somatic Genomic Landscape of Chromophobe Renal Cell Carcinoma. Cancer Cell 2014, 26, 319-330. [CrossRef] 
29. Mollica, V.; Franceschini, T.; Gruppioni, E.; Rizzo, A.; Ricci, C.; Schiavina, R.; Brunocilla, E.; Ardizzoni, A.; Fiorentino, M.; Giunchi, F.; et al. Broad spectrum mutational analysis of chromophobe renal cell carcinoma using next-generation sequencing. Pathol.-Res. Pr. 2021, 219, 153350. [CrossRef]

30. Yang, P.; Cornejo, K.M.; Sadow, P.; Cheng, L.; Wang, M.; Xiao, Y.; Jiang, Z.; Oliva, E.; Jozwiak, S.; Nussbaum, R.L.; et al. Renal Cell Carcinoma in Tuberous Sclerosis Complex. Am. J. Surg. Pathol. 2014, 38, 895-909. [CrossRef]

31. Ged, Y.; Chen, Y.-B.; Knezevic, A.; Casuscelli, J.; Redzematovic, A.; DiNatale, R.G.; Carlo, M.I.; Lee, C.-H.; Feldman, D.R.; Patil, S.; et al. Metastatic Chromophobe Renal Cell Carcinoma: Presence or Absence of Sarcomatoid Differentiation Determines Clinical Course and Treatment Outcomes. Clin. Genitourin. Cancer 2019, 17, e678-e688. [CrossRef] [PubMed]

32. Kyriakopoulos, C.E.; Chittoria, N.; Choueiri, T.K.; Kroeger, N.; Lee, J.-L.; Srinivas, S.; Knox, J.J.; Bjarnason, G.A.; Ernst, S.D.; Wood, L.A.; et al. Outcome of Patients With Metastatic Sarcomatoid Renal Cell Carcinoma: Results From the International Metastatic Renal Cell Carcinoma Database Consortium. Clin. Genitourin. Cancer 2015, 13, e79-e85. [CrossRef]

33. Przybycin, C.G.; McKenney, J.K.; Reynolds, J.P.; Campbell, S.; Zhou, M.; Karafa, M.T.; Magi-Galluzzi, C. Rhabdoid Differentiation Is Associated With Aggressive Behavior in Renal Cell Carcinoma. Am. J. Surg. Pathol. 2014, 38, 1260-1265. [CrossRef] [PubMed]

34. Jones, T.D.; Eble, J.N.; Wang, M.; MacLennan, G.T.; Jain, S.; Cheng, L. Clonal divergence and genetic heterogeneity in clear cell renal cell carcinomas with sarcomatoid transformation. Cancer 2005, 104, 1195-1203. [CrossRef]

35. Bakouny, Z.; Braun, D.A.; Shukla, S.A.; Pan, W.; Gao, X.; Hou, Y.; Flaifel, A.; Tang, S.; Bosma-Moody, A.; He, M.X.; et al. Integrative molecular characterization of sarcomatoid and rhabdoid renal cell carcinoma. Nat. Commun. 2021, 12, 1-14. [CrossRef] [PubMed]

36. Malouf, G.G.; Flippot, R.; Dong, Y.; DiNatale, R.G.; Chen, Y.-B.; Su, X.; Compérat, E.; Rouprêt, M.; Mano, R.; Blum, K.A.; et al. Molecular characterization of sarcomatoid clear cell renal cell carcinoma unveils new candidate oncogenic drivers. Sci. Rep. 2020, 10, 1-10. [CrossRef]

37. Wang, Z.; Kim, T.B.; Peng, B.; Karam, J.A.; Creighton, C.J.; Joon, A.; Kawakami, F.; Trevisan, P.; Jonasch, E.; Chow, C.-W.; et al. Sarcomatoid Renal Cell Carcinoma Has a Distinct Molecular Pathogenesis, Driver Mutation Profile, and Transcriptional Landscape. Clin. Cancer Res. 2017, 23, 6686-6696. [CrossRef] [PubMed]

38. Singh, R.R.; Murugan, P.; Patel, L.R.; Voicu, H.; Yoo, S.-Y.; Majewski, T.; Mehrotra, M.; Wani, K.; Tannir, N.M.; Karam, J.A.; et al. Intratumoral morphologic and molecular heterogeneity of rhabdoid renal cell carcinoma: Challenges for personalized therapy. Mod. Pathol. 2015, 28, 1225-1235. [CrossRef] [PubMed]

39. Dizman, N.; Philip, E.J.; Pal, S.K. Genomic profiling in renal cell carcinoma. Nat. Rev. Nephrol. 2020, 16, 1-17. [CrossRef]

40. Bi, M.; Zhao, S.; Said, J.W.; Merino, M.J.; Adeniran, A.J.; Xie, Z.; Nawaf, C.B.; Choi, J.; Belldegrun, A.S.; Pantuck, A.J.; et al. Genomic characterization of sarcomatoid transformation in clear cell renal cell carcinoma. Proc. Natl. Acad. Sci. USA 2016, 113, 2170-2175. [CrossRef] [PubMed]

41. Mattelaer, P.; Wolff, J.M.; Brauers, A.; Ijzerman, W.; Füzesi, L.; Jakse, G. Bellini duct carcinoma: A rare variant of renal cell carcinoma. Acta Urol. Belg. 1996, 64, 33-35. [PubMed]

42. Orsola, A.; Trias, I.; Raventós, C.; Español, I.; Cecchini, L.; Orsola, I. Renal collecting (Bellini) duct carcinoma displays similar characteristics to upper tract urothelial cell carcinoma. Urology 2005, 65, 49-54. [CrossRef] [PubMed]

43. Milowsky, M.I.; Rosmarin, A.S.; Tickoo, S.K.; Papanicolaou, N.; Nanus, D.M. Active chemotherapy for collecting duct carcinoma of the kidney. Cancer 2001, 94, 111-116. [CrossRef]

44. Pal, S.K.; Choueiri, T.K.; Wang, K.; Khaira, D.; Karam, J.A.; Van Allen, E.; Palma, N.A.; Stein, M.N.; Johnson, A.; Squillace, R.; et al. Characterization of Clinical Cases of Collecting Duct Carcinoma of the Kidney Assessed by Comprehensive Genomic Profiling. Eur. Urol. 2016, 70, 516-521. [CrossRef]

45. Camparo, P.; Vasiliu, V.; Molinie, V.; Couturier, J.; Dykema, K.J.; Petillo, D.; Furge, K.A.; Comperat, E.M.; Lae, M.; Bouvier, R.; et al. Renal Translocation Carcinomas: Clinicopathologic, immunohistochemical, and gene expression profiling analysis of 31 cases with a review of the literature. Am. J. Surg. Pathol. 2008, 32, 656-670. [CrossRef] [PubMed]

46. Warren, A.Y.; Harrison, D. WHO/ISUP classification, grading and pathological staging of renal cell carcinoma: Standards and controversies. World J. Urol. 2018, 36, 1913-1926. [CrossRef]

47. Argani, P.; Olgac, S.; Tickoo, S.K.; Goldfischer, M.; Moch, H.; Chan, D.Y.; Eble, J.N.; Bonsib, S.M.; Jimeno, M.; Lloreta, J.; et al. Xp11 Translocation Renal Cell Carcinoma in Adults: Expanded Clinical, Pathologic, and Genetic Spectrum. Am. J. Surg. Pathol. 2007, 31, 1149-1160. [CrossRef]

48. Mir, M.C.; Trilla, E.; De Torres, I.M.; Panizo, Á.; Zlotta, A.R.; Van Rhijn, B.; Morote, J. Altered transcription factor E3 expression in unclassified adult renal cell carcinoma indicates adverse pathological features and poor outcome. BJU Int. 2010, 108, E71-E76. [CrossRef] [PubMed]

49. Geller, J.I.; Argani, P.; Adeniran, A.; Hampton, E.; De Marzo, A.; Hicks, J.; Collins, M.H. Translocation renal cell carcinoma: Lack of negative impact due to lymph node spread. Cancer 2008, 112, 1607-1616. [CrossRef]

50. Msaouel, P.; Hong, A.L.; Mullen, E.A.; Atkins, M.B.; Walker, C.L.; Lee, C.-H.; Carden, M.A.; Genovese, G.; Linehan, W.M.; Rao, P.; et al. Updated Recommendations on the Diagnosis, Management, and Clinical Trial Eligibility Criteria for Patients With Renal Medullary Carcinoma. Clin. Genitourin. Cancer 2019, 17, 1-6. [CrossRef] [PubMed]

51. Msaouel, P.; Malouf, G.G.; Su, X.; Yao, H.; Tripathi, D.N.; Soeung, M.; Gao, J.; Rao, P.; Coarfa, C.; Creighton, C.J.; et al. Comprehensive Molecular Characterization Identifies Distinct Genomic and Immune Hallmarks of Renal Medullary Carcinoma. Cancer Cell 2020, 37, 720-734.e13. [CrossRef] [PubMed] 
52. Jeong, J.-H.; Ojha, U.; Lee, Y.M. Pathological angiogenesis and inflammation in tissues. Arch. Pharmacal Res. 2021, 44, 1-15. [CrossRef] [PubMed]

53. Santoni, M.; Bracarda, S.; Nabissi, M.; Massari, F.; Conti, A.; Bria, E.; Tortora, G.; Santoni, G.; Cascinu, S. CXC and CC Chemokines as Angiogenic Modulators in Nonhaematological Tumors. BioMed Res. Int. 2014, 2014, 1-12. [CrossRef] [PubMed]

54. Vaupel, P.; Mayer, A. Tumor Hypoxia: Causative Mechanisms, Microregional Heterogeneities, and the Role of Tissue-Based Hypoxia Markers. Adv. Exp. Med. Biol. 2016, 923, 77-86. [CrossRef] [PubMed]

55. Roskoski, R. Vascular endothelial growth factor (VEGF) and VEGF receptor inhibitors in the treatment of renal cell carcinomas. Pharmacol. Res. 2017, 120, 116-132. [CrossRef] [PubMed]

56. Choueiri, T.K.; Jr, W.G.K. Targeting the HIF2-VEGF axis in renal cell carcinoma. Nat. Med. 2020, 26, 1-12. [CrossRef]

57. Ljungberg, B.J.; Jacobsen, J.; Rudolfsson, S.H.; Lindh, G.; Grankvist, K.; Rasmuson, T. Different vascular endothelial growth factor (VEGF), VEGF-receptor 1 and -2 mRNA expression profiles between clear cell and papillary renal cell carcinoma. BJU Int. 2006, 98, 661-667. [CrossRef]

58. Li, Z.-C.; Zhai, G.; Zhang, J.; Wang, Z.; Liu, G.; Wu, G.-Y.; Liang, D.; Zheng, H. Differentiation of clear cell and non-clear cell renal cell carcinomas by all-relevant radiomics features from multiphase CT: A VHL mutation perspective. Eur. Radiol. 2018, 29, 3996-4007. [CrossRef]

59. Stenehjem, D.D.; Hahn, A.W.; Gill, D.M.; Albertson, D.; Gowrishankar, B.; Merriman, J.; Agarwal, A.M.; Thodima, V.; Harrington, E.B.; Au, T.H.; et al. Predictive genomic markers of response to VEGF targeted therapy in metastatic renal cell carcinoma. PLoS ONE 2019, 14, e0210415. [CrossRef]

60. Armstrong, A.J.; Halabi, S.; Eisen, T.; Broderick, S.; Stadler, W.M.; Jones, R.J.; Garcia, J.A.; Vaishampayan, U.N.; Picus, J.; Hawkins, R.E.; et al. Everolimus versus sunitinib for patients with metastatic non-clear cell renal cell carcinoma (ASPEN): A multicentre, open-label, randomised phase 2 trial. Lancet Oncol. 2016, 17, 378-388. [CrossRef]

61. Tannir, N.M.; Jonasch, E.; Albiges, L.; Altinmakas, E.; Ng, C.S.; Matin, S.F.; Wang, X.; Qiao, W.; Lim, Z.D.; Tamboli, P.; et al. Everolimus Versus Sunitinib Prospective Evaluation in Metastatic Non-Clear Cell Renal Cell Carcinoma (ESPN): A Randomized Multicenter Phase 2 Trial. Eur. Urol. 2016, 69, 866-874. [CrossRef]

62. Motzer, R.J.; Barrios, C.H.; Kim, T.M.; Falcon, S.; Cosgriff, T.; Harker, W.G.; Srimuninnimit, V.; Pittman, K.; Sabbatini, R.; Rha, S.Y.; et al. Phase II Randomized Trial Comparing Sequential First-Line Everolimus and Second-Line Sunitinib Versus First-Line Sunitinib and Second-Line Everolimus in Patients With Metastatic Renal Cell Carcinoma. J. Clin. Oncol. 2014, 32, $2765-2772$. [CrossRef] [PubMed]

63. Hsieh, J.J.; Chen, D.; Wang, P.I.; Marker, M.; Redzematovic, A.; Chen, Y.-B.; Selcuklu, S.D.; Weinhold, N.; Bouvier, N.; Huberman, K.H.; et al. Genomic Biomarkers of a Randomized Trial Comparing First-line Everolimus and Sunitinib in Patients with Metastatic Renal Cell Carcinoma. Eur. Urol. 2017, 71, 405-414. [CrossRef] [PubMed]

64. Bergmann, L.; Grünwald, V.; Maute, L.; Grimm, M.-O.; Weikert, S.; Schleicher, J.; Klotz, T.; Greiner, J.; Flörcken, A.; Hartmann, A.; et al. A Randomized Phase IIa Trial with Temsirolimus versus Sunitinib in Advanced Non-Clear Cell Renal Cell Carcinoma: An Intergroup Study of the CESAR Central European Society for Anticancer Drug Research-EWIV and the Interdisciplinary Working Group on Renal Cell Cancer (IAGN) of the German Cancer Society. Oncol. Res. Treat. 2020, 43, 333-339. [CrossRef]

65. Ravaud, A.; Oudard, S.; De Fromont, M.; Chevreau, C.; Gravis, G.; Zanetta, S.; Theodore, C.; Jimenez, M.; Sevin, E.; Laguerre, B.; et al. First-line treatment with sunitinib for type 1 and type 2 locally advanced or metastatic papillary renal cell carcinoma: A phase II study (SUPAP) by the French Genitourinary Group (GETUG). Ann. Oncol. 2015, 26, 1123-1128. [CrossRef] [PubMed]

66. Feldman, D.R.; Ged, Y.; Lee, C.; Ms, A.K.; Molina, A.M.; Chen, Y.; Chaim, J.; Ms, D.T.C.; Murray, S.; Tickoo, S.K.; et al. Everolimus plus bevacizumab is an effective first-line treatment for patients with advanced papillary variant renal cell carcinoma: Final results from a phase II trial. Cancer 2020, 126, 5247-5255. [CrossRef]

67. Bhatt, R.S.; Wang, X.; Zhang, L.; Collins, M.P.; Signoretti, S.; Alsop, D.C.; Goldberg, S.N.; Atkins, M.B.; Mier, J.W. Renal Cancer Resistance to Antiangiogenic Therapy Is Delayed by Restoration of Angiostatic Signaling. Mol. Cancer Ther. 2010, 9, $2793-2802$. [CrossRef] [PubMed]

68. Choueiri, T.K.; Plantade, A.; Elson, P.; Negrier, S.; Ravaud, A.; Oudard, S.; Zhou, M.; Rini, B.I.; Bukowski, R.M.; Escudier, B. Efficacy of Sunitinib and Sorafenib in Metastatic Papillary and Chromophobe Renal Cell Carcinoma. J. Clin. Oncol. 2008, 26, 127-131. [CrossRef] [PubMed]

69. Bersanelli, M.; Brunelli, M.; Gnetti, L.; Maestroni, U.; Buti, S. Pazopanib as a possible option for the treatment of metastatic non-clear cell renal carcinoma patients: A systematic review. Ther. Adv. Med Oncol. 2020, 12. [CrossRef]

70. Hua, H.; Kong, Q.; Zhang, H.; Wang, J.; Luo, T.; Jiang, Y. Targeting mTOR for cancer therapy. J. Hematol. Oncol. 2019, 12, 1-19. [CrossRef] [PubMed]

71. Linehan, W.M.; Srinivasan, R.; Schmidt, L.S. The genetic basis of kidney cancer: A metabolic disease. Nat. Rev. Urol. 2010, 7, 277-285. [CrossRef]

72. Choueiri, T.K.; Bauer, T.M.; Papadopoulos, K.P.; Plimack, E.R.; Merchan, J.R.; McDermott, D.F.; Michaelson, M.D.; Appleman, L.J.; Thamake, S.; Perini, R.F.; et al. Inhibition of hypoxia-inducible factor- $2 \alpha$ in renal cell carcinoma with belzutifan: A phase 1 trial and biomarker analysis. Nat. Med. 2021, 27, 802-805. [CrossRef]

73. Ramkumar, R.R.; Murthy, P.B.; Nguyen, J.K.; McKenney, J.; Eng, C.; Campbell, S.C. PTEN Hamartoma Tumor Syndrome: A Case of Renal Cell Carcinoma in a Young Female. Urol. 2021, 148, 113-117. [CrossRef]

74. Trnka, P.; Kennedy, S.E. Renal tumors in tuberous sclerosis complex. Pediatr. Nephrol. 2021, 36, 1427-1438. [CrossRef] [PubMed] 
75. Bissler, J.J.; Kingswood, J.C.; Radzikowska, E.; Zonnenberg, B.A.; Frost, M.; Belousova, E.; Sauter, M.; Nonomura, N.; Brakemeier, S.; de Vries, P.J.; et al. Everolimus for angiomyolipoma associated with tuberous sclerosis complex or sporadic lymphangioleiomyomatosis (EXIST-2): A multicentre, randomised, double-blind, placebo-controlled trial. Lancet 2013, 381, 817-824. [CrossRef]

76. Reyes, J.M.J.R.; Cuesta, R.; Pause, A. Folliculin: A Regulator of Transcription through AMPK and mTOR Signaling Pathways. Front. Cell Dev. Biol. 2021, 9. [CrossRef]

77. Schmidt, L.S.; Linehan, W.M. Molecular genetics and clinical features of Birt-Hogg-Dubé syndrome. Nat. Rev. Urol. 2015, 12, 558-569. [CrossRef]

78. Argani, P.; Hicks, J.; De Marzo, A.M.; Albadine, R.; Illei, P.B.; Ladanyi, M.; Reuter, V.E.; Netto, G.J. Xp11 Translocation Renal Cell Carcinoma (RCC): Extended Immunohistochemical Profile Emphasizing Novel RCC Markers. Am. J. Surg. Pathol. 2010, 34, 1295-1303. [CrossRef] [PubMed]

79. Damayanti, N.P.; Budka, J.A.; Khella, H.W.; Ferris, M.W.; Ku, S.Y.; Kauffman, E.; Wood, A.C.; Ahmed, K.; Chintala, V.N.; Adelaiye-Ogala, R.; et al. Therapeutic Targeting of TFE3/IRS-1/PI3K/mTOR Axis in Translocation Renal Cell Carcinoma. Clin. Cancer Res. 2018, 24, 5977-5989. [CrossRef]

80. Morris, M.R.; Maina, E.; Morgan, N.V.; Gentle, D.; Astuti, D.; Moch, H.; Kishida, T.; Yao, M.; Schraml, P.; Richards, F.M.; et al. Molecular genetic analysis of FIH-1, FH, and SDHB candidate tumour suppressor genes in renal cell carcinoma. J. Clin. Pathol. 2004, 57, 706-711. [CrossRef]

81. Aghamir, S.M.K.; Heshmat, R.; Ebrahimi, M.; Ketabchi, S.E.; Dizaji, S.P.; Khatami, F. The Impact of Succinate Dehydrogenase Gene (SDH) Mutations In Renal Cell Carcinoma (RCC): A Systematic Review. OncoTargets Ther. 2019, ume 12, 7929-7940. [CrossRef]

82. Ciccarese, C.; Iacovelli, R.; Brunelli, M.; Massari, F.; Bimbatti, D.; Fantinel, E.; De Marco, V.; Porcaro, A.B.; Martignoni, G.; Artibani, W.; et al. Addressing the best treatment for non-clear cell renal cell carcinoma: A meta-analysis of randomised clinical trials comparing VEGFR-TKis versus mTORi-targeted therapies. Eur. J. Cancer 2017, 83, 237-246. [CrossRef]

83. Escudier, B.; Molinie, V.; Bracarda, S.; Maroto, P.; Szczylik, C.; Nathan, P.; Negrier, S.; Weiss, C.; Porta, C.; Grünwald, V.; et al. Open-label phase 2 trial of first-line everolimus monotherapy in patients with papillary metastatic renal cell carcinoma: RAPTOR final analysis. Eur. J. Cancer 2016, 69, 226-235. [CrossRef]

84. Blank, C.U.; Bono, P.; Larkin, J.M.G.; Gogov, S.; Panneerselvam, A.; Garay, C.A.; Grünwald, V. Safety and Efficacy of Everolimus in Patients with Non-Clear Cell Renal Cell Carcinoma Refractory to VEGF-Targeted Therapy: Subgroup Analysis of REACT. J. Clin. Oncol. 2012, 30 (Suppl. 5), 402. [CrossRef]

85. Koh, Y.; Lim, H.Y.; Ahn, J.H.; Lee, J.-L.; Rha, S.Y.; Kim, Y.J.; Kim, T.M.; Lee, S.-H. Phase II trial of everolimus for the treatment of nonclear-cell renal cell carcinoma. Ann. Oncol. 2013, 24, 1026-1031. [CrossRef] [PubMed]

86. Venugopal, B.; Ansari, J.; Aitchison, M.; Tho, L.M.; Campbell, R.; Jones, R.J. Efficacy of temsirolimus in metastatic chromophobe renal cell carcinoma. BMC Urology 2013, 13, 26. [CrossRef] [PubMed]

87. Dutcher, J.P.; De Souza, P.; McDermott, D.; Figlin, R.A.; Berkenblit, A.; Thiele, A.; Krygowski, M.; Strahs, A.; Feingold, J.; Hudes, G. Effect of temsirolimus versus interferon- $\alpha$ on outcome of patients with advanced renal cell carcinoma of different tumor histologies. Med. Oncol. 2009, 26, 202-209. [CrossRef]

88. Garajová, I.; Giovannetti, E.; Biasco, G.; Peters, G.J. c-Met as a Target for Personalized Therapy. Transl. Oncogenomics 2015, 7 (Suppl. 1), 13-31. [CrossRef] [PubMed]

89. Massari, F.; Di Nunno, V.; Santoni, M.; Gatto, L.; Caserta, C.; Morelli, F.; Zafarana, E.; Carrozza, F.; Mosca, A.; Mollica, V.; et al. Toward a genome-based treatment landscape for renal cell carcinoma. Crit. Rev. Oncol. Hematol. 2019, 142, 141-152. [CrossRef] [PubMed]

90. Mollica, V.; Di Nunno, V.; Gatto, L.; Santoni, M.; Scarpelli, M.; Cimadamore, A.; Lopez-Beltran, A.; Cheng, L.; Battelli, N.; Montironi, R.; et al. Resistance to Systemic Agents in Renal Cell Carcinoma Predict and Overcome Genomic Strategies Adopted by Tumor. Cancers 2019, 11, 830. [CrossRef] [PubMed]

91. Albiges, L.; Guegan, J.; Le Formal, A.; Verkarre, V.; Rioux-Leclercq, N.; Sibony, M.; Bernhard, J.-C.; Camparo, P.; Merabet, Z.; Molinie, V.; et al. MET Is a Potential Target across All Papillary Renal Cell Carcinomas: Result from a Large Molecular Study of pRCC with CGH Array and Matching Gene Expression Array. Clin. Cancer Res. 2014, 20, 3411-3421. [CrossRef] [PubMed]

92. Pal, S.K.; Tangen, C.; Thompson, I.M.; Balzer-Haas, N.; George, D.J.; Heng, D.Y.C.; Shuch, B.; Stein, M.; Tretiakova, M.; Humphrey, P.; et al. A comparison of sunitinib with cabozantinib, crizotinib, and savolitinib for treatment of advanced papillary renal cell carcinoma: A randomised, open-label, phase 2 trial. Lancet 2021, 397, 695-703. [CrossRef]

93. Choueiri, T.K.; Powles, T.; Burotto, M.; Escudier, B.; Bourlon, M.T.; Zurawski, B.; Juárez, V.M.O.; Hsieh, J.J.; Basso, U.; Shah, A.Y.; et al. Nivolumab plus Cabozantinib versus Sunitinib for Advanced Renal-Cell Carcinoma. N. Engl. J. Med. 2021, 384, 829-841. [CrossRef]

94. McGregor, B.; Agarwal, N.; Suarez, C.; Tsao, C.-K.; Kelly, W.; Pagliaro, L.; Vaishampayan, U.; Castellano, D.; Loriot, Y.; Werneke, S.; et al. 709P Cabozantinib (C) in combination with atezolizumab (A) in non-clear cell renal cell carcinoma (nccRCC): Results from cohort 10 of the COSMIC-021 study. Ann. Oncol. 2020, 31, S558. [CrossRef]

95. Choueiri, T.K.; Plimack, E.; Arkenau, H.-T.; Jonasch, E.; Heng, D.Y.C.; Powles, T.; Frigault, M.M.; Clark, E.A.; Handzel, A.A.; Gardner, H.; et al. Biomarker-Based Phase II Trial of Savolitinib in Patients With Advanced Papillary Renal Cell Cancer. J. Clin. Oncol. 2017, 35, 2993-3001. [CrossRef] 
96. Choueiri, T.K.; Heng, D.Y.C.; Lee, J.L.; Cancel, M.; Verheijen, R.B.; Mellemgaard, A.; Ottesen, L.H.; Frigault, M.M.; L'Hernault, A.; Szijgyarto, Z.; et al. Efficacy of Savolitinib vs Sunitinib in Patients With MET-Driven Papillary Renal Cell Carcinoma: The SAVOIR Phase 3 Ran-domized Clinical Trial. JAMA Oncol. 2020, 6, 1247-1255. [CrossRef] [PubMed]

97. Mollica, V.; Rizzo, A.; Massari, F. Re: Toni K. Choueiri, Daniel Y.C. Heng, Jae Lyun Lee; et al. Efficacy of Savolitinib vs. Sunitinib in Patients With MET-Driven Papillary Renal Cell Carcinoma: The SAVOIR Phase 3 Randomized Clinical Trial. JAMA Oncol. In press. https://doi-org.ezproxy.unibo.it/10.1001/jamaoncol.2020.2218: SAVOIR: From Own Goal to Winning Goal? Eur. Urol. Oncol. 2020, 3, 561-562. [CrossRef] [PubMed]

98. Schöffski, P.; Wozniak, A.; Escudier, B.; Rutkowski, P.; Anthoney, A.; Bauer, S.; Sufliarsky, J.; van Herpen, C.; Lindner, L.H.; Grünwald, V.; et al. Crizotinib achieves long-lasting disease control in advanced papillary renal-cell carcinoma type 1 patients with MET mutations or amplification. EORTC 90101 CREATE trial. Eur. J. Cancer 2017, 87, 147-163. [CrossRef] [PubMed]

99. Choueiri, T.K.; Vaishampayan, U.; Rosenberg, J.E.; Logan, T.F.; Harzstark, A.L.; Bukowski, R.M.; Rini, B.I.; Srinivas, S.; Stein, M.N.; Adams, L.M.; et al. Phase II and Biomarker Study of the Dual MET/VEGFR2 Inhibitor Foretinib in Patients With Papillary Renal Cell Carcinoma. J. Clin. Oncol. 2013, 31, 181-186. [CrossRef] [PubMed]

100. Twardowski, P.W.; Tangen, C.M.; Wu, X.; Plets, M.R.; Plimack, E.R.; Agarwal, N.; Vogelzang, N.J.; Wang, J.; Tao, S.; Thompson, I.M.; et al. Parallel (Randomized) Phase II Evaluation of Tivantinib (ARQ197) and Tivantinib in Combination with Erlotinib in Papillary Renal Cell Carcinoma: SWOG S1107. Kidney Cancer 2017, 1, 123-132. [CrossRef] [PubMed]

101. Tsuda, M.; Davis, I.J.; Argani, P.; Shukla, N.; McGill, G.G.; Nagai, M.; Saito, T.; Laé, M.; Fisher, D.E.; Ladanyi, M. TFE3 Fusions Activate MET Signaling by Transcriptional Up-regulation, Defining Another Class of Tumors as Candidates for Therapeutic MET Inhibition. Cancer Res. 2007, 67, 919-929. [CrossRef] [PubMed]

102. Wagner, A.J.; Goldberg, J.M.; Dubois, S.G.; Choy, E.; Rosen, L.; Pappo, A.; Geller, J.; Judson, I.; Hogg, D.; Senzer, N.; et al. Tivantinib (ARQ 197), a selective inhibitor of MET, in patients with microphthalmia transcription factor-associated tumors: Results of a multicenter phase 2 trial. Cancer 2012, 118, 5894-5902. [CrossRef] [PubMed]

103. Lawrence, M.S.; Stojanov, P.; Polak, P.; Kryukov, G.V.; Cibulskis, K.; Sivachenko, A.; Carter, S.L.; Stewart, C.; Mermel, C.H.; Roberts, S.A.; et al. Mutational heterogeneity in cancer and the search for new cancer-associated genes. Nat. Cell Biol. 2013, 499, 214-218. [CrossRef]

104. Massari, F.; Di Nunno, V.; Mollica, V.; Montironi, R.; Cheng, L.; Cimadamore, A.; Blanca, A.; Lopez-Beltran, A. Immunotherapy in renal cell carcinoma from poverty to the spoiled of choice. Immunotherapy 2019, 11, 1507-1521. [CrossRef] [PubMed]

105. Santoni, M.; Buti, S.; Conti, A.; Porta, C.; Procopio, G.; Sternberg, C.N.; Bracarda, S.; Basso, U.; De Giorgi, U.; Rizzo, M.; et al. Prognostic significance of host immune status in patients with late relapsing renal cell carcinoma treated with targeted therapy. Target. Oncol. 2015, 10, 517-522. [CrossRef]

106. Chen, D.S.; Mellman, I. Elements of cancer immunity and the cancer-immune set point. Nature 2017, 541, 321-330. [CrossRef]

107. Ricketts, C.J.; De Cubas, A.A.; Fan, H.; Smith, C.C.; Lang, M.; Reznik, E.; Bowlby, R.; Gibb, E.A.; Akbani, R.; Beroukhim, R.; et al. The Cancer Genome Atlas Comprehensive Molecular Characterization of Renal Cell Carcinoma. Cell Rep. 2018, 23, 313-326.e5. [CrossRef]

108. Braun, D.A.; Hou, Y.; Bakouny, Z.; Ficial, M.; Angelo, M.S.; Forman, J.; Ross-Macdonald, P.; Berger, A.C.; Jegede, O.A.; Elagina, L.; et al. Interplay of somatic alterations and immune infiltration modulates response to PD-1 blockade in advanced clear cell renal cell carcinoma. Nat. Med. 2020, 26, 909-918. [CrossRef]

109. Motzer, R.J.; Escudier, B.; McDermott, D.F.; George, S.; Hammers, H.J.; Srinivas, S.; Tykodi, S.S.; Sosman, J.A.; Procopio, G.; Plimack, E.R.; et al. Nivolumab versus Everolimus in Advanced Renal-Cell Carcinoma. N. Engl. J. Med. 2015, 373, 1803-1813. [CrossRef]

110. McDermott, D.F.; Lee, J.-L.; Ziobro, M.; Suarez, C.; Langiewicz, P.; Matveev, V.B.; Wiechno, P.; Gafanov, R.A.; Tomczak, P.; Pouliot, F; et al. Open-Label, Single-Arm, Phase II Study of Pembrolizumab Monotherapy as First-Line Therapy in Patients With Advanced Non-Clear Cell Renal Cell Carcinoma. J. Clin. Oncol. 2021, 39, 1029-1039. [CrossRef] [PubMed]

111. Lee, C.-H.; Voss, M.H.; Carlo, M.I.; Chen, Y.-B.; Reznik, E.; Knezevic, A.; Lefkowitz, R.A.; Shapnik, N.; Tassone, D.; Dadoun, C.; et al. Nivolumab plus cabozantinib in patients with non-clear cell renal cell carcinoma: Results of a phase 2 trial. J. Clin. Oncol. 2021, 39, 4509. [CrossRef]

112. McKay, R.R.; McGregor, B.A.; Gray, K.; Steinharter, J.A.; Walsh, M.K.; Braun, D.A.; Flaifel, A.; VanAllen, E.; Wei, X.X.; Signoretti, S.; et al. Results of a phase II study of atezolizumab and bevacizumab in non-clear cell renal cell carcinoma (nccRCC) and clear cell renal cell carcinoma with sarcomatoid differentiation (sccRCC). J. Clin. Oncol. 2019, 37, 548. [CrossRef]

113. Powles, T.; Larkin, J.M.G.; Patel, P.; Pérez-Valderrama, B.; Rodriguez-Vida, A.; Glen, H.; Thistlethwaite, F.; Ralph, C.; Srinivasan, G.; Mendez-Vidal, M.J.; et al. A phase II study investigating the safety and efficacy of savolitinib and durvalumab in metastatic papillary renal cancer (CALYPSO). J. Clin. Oncol. 2019, 37, 545. [CrossRef]

114. Pal, S.K.; Tsao, C.K.; Suarez, C.; Kelly, W.; Pagliaro, L.; Vaishampayan, U.N.; Loriot, Y.; Srinivas, S.; McGregor, B.A.; Panneerselvam, A.; et al. 702O-Cabozantinib (C) in combination with atezolizumab (A) as first-line therapy for advanced clear cell renal cell carcinoma (ccRCC): Results from the COSMIC-021 study. Ann. Oncol. 2020, 31 (Suppl. 4), S550. [CrossRef]

115. Choueiri, T.K.; Albiges, L.; Powles, T.; Scheffold, C.; Wang, F.; Motzer, R.J. A phase III study (COSMIC-313) of cabozantinib (C) in combination with nivolumab (N) and ipilimumab (I) in patients (pts) with previously untreated advanced renal cell carcinoma (aRCC) of intermediate or poor risk. J. Clin. Oncol. 2020, 38, TPS767. [CrossRef] 
116. Lee, C.-H.; Li, C.; Perini, R.F.; Hoehn, D.; Albiges, L. KEYNOTE-B61: Open-label phase 2 study of pembrolizumab in combination with lenvatinib as first-line treatment for non-clear cell renal cell carcinoma (nccRCC). J. Clin. Oncol. 2021, 39, TPS4595. [CrossRef]

117. Hanif, A.; Pandey, M.; Khan, S.; Attwood, K.; George, S. Metastatic sarcomatoid renal cell carcinoma treated with immune checkpoint inhibitors. OncoImmunology 2019, 8, 1606639. [CrossRef] [PubMed]

118. Tannir, N.M.; Signoretti, S.; Choueiri, T.K.; McDermott, D.F.; Motzer, R.J.; Flaifel, A.; Pignon, J.-C.; Ficial, M.; Frontera, O.A.; George, S.; et al. Efficacy and Safety of Nivolumab Plus Ipilimumab versus Sunitinib in First-line Treatment of Patients with Advanced Sarcomatoid Renal Cell Carcinoma. Clin. Cancer Res. 2021, 27, 78-86. [CrossRef] [PubMed]

119. Choueiri, T.K.; Larkin, J.M.G.; Pal, S.K.; Motzer, R.J.; Venugopal, B.; Alekseev, B.Y.; Miyake, H.; Gravis, G.; Bilen, M.A.; Chudnovsky, A.; et al. DEfficacy and biomarker analysis of patients (pts) with advanced renal cell carcinoma (aRCC) with sarcomatoid histology (sRCC): Subgroup analysis from the phase III JAVELIN renal 101 trial of first-line avelumab plus axitinib $(\mathrm{A}+\mathrm{Ax})$ vs. sunitinib (S). Ann. Oncol. 2019, 30 (Suppl. 5), v356-v402. [CrossRef]

120. Rini, B.I.; Motzer, R.J.; Powles, T.; McDermott, D.F.; Escudier, B.; Donskov, F.; Hawkins, R.E.; Bracarda, S.; Bedke, J.; De Giorgi, U.; et al. Atezolizumab (atezo) + bevacizumab (bev) versus sunitinib (sun) in pts with untreated metastatic renal cell carcinoma (mRCC) and sarcomatoid (sarc) histology: IMmotion151 subgroup analysis. J. Clin. Oncol. 2019, 37, 4512. [CrossRef]

121. Rini, B.I.; Plimack, E.R.; Stus, V.; Gafanov, R.; Hawkins, R.; Nosov, D.; Pouliot, F.; Soulieres, D.; Melichar, B.; Vynnychenko, I.; et al. Pembrolizumab (pembro) plus axitinib (axi) versus sunitinib as first-line therapy for metastatic renal cell carcinoma (mRCC): Outcomes in the combined IMDC intermediate/poor risk and sarcomatoid subgroups of the phase 3 KEYNOTE-426 study. $J$. Clin. Oncol. 2019, 37, 4500. [CrossRef]

122. Motzer, R.J.; Choueiri, T.K.; Powles, T.; Burotto, M.; Bourlon, M.T.; Hsieh, J.; Maruzzo, M.; Shah, A.Y.; Suarez, C.; Barrios, C.H.; et al. Nivolumab + cabozantinib (NIVO+CABO) vs. sunitinib (SUN) for advanced renal cell carcinoma (aRCC): Outcomes by sarcomatoid histology and updated trial results with extended follow-up of CheckMate-9ER. Abstract presented at: ASCO Genitourinary Cancers Symposium; 13 February 2021. Available online: https://meetinglibrary.asco.org/record/195192/abstract (accessed on 13 February 2021).

123. Santoni, M.; Massari, F.; Aurilio, G.; Mollica, V.; Cimadamore, A.; Lopez-Beltran, A.; Cheng, L.; Battelli, N.; Nolé, F.; Montironi, R. Designing novel immunocombinations in metastatic renal cell carcinoma. Immunotherapy 2020, 12, 1257-1268. [CrossRef] [PubMed]

124. Costa, J.G.; Saraiva, N.; Batinic-Haberle, I.; Castro, M.; Oliveira, N.G.; Fernandes, A.S. The SOD Mimic MnTnHex-2-PyP5+ Reduces the Viability and Migration of 786-O Human Renal Cancer Cells. Antioxidants 2019, 8, 490. [CrossRef] [PubMed]

125. Gulati, S.; Philip, E.; Salgia, S.; Pal, S.K. Evolving treatment paradigm in metastatic non clear cell renal cell carcinoma. Cancer Treat Res. Commun. 2020, 23, 100172. [CrossRef] [PubMed] 